\title{
A presença do Novo Mundo na iconografia da morte e dos sonhos de São Francisco Xavier \\ a missão jesuítica e as partes e gentes do Império Português*
}

\section{The presence of the New World in Saint Francis Xavier's death and dreams iconography}

Jesuit mission and the parts and peoples of the Portuguese Empire

\author{
LUÍS FILIPE SILVÉRIO LIMA** \\ Departamento de História \\ Universidade Federal de São Paulo \\ Guarulhos (SP) \\ Brasil
}

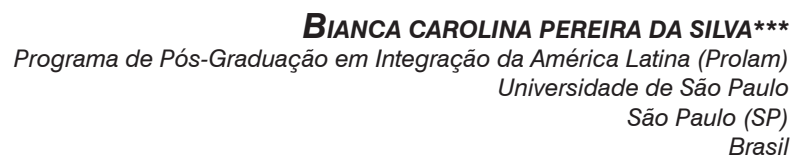

RESUMO A proposta deste artigo é analisar diferentes leituras pictóricas da morte e dos sonhos de S. Francisco Xavier, desde inícios do século XVII até

\footnotetext{
* Artigo recebido em: 15/05/2013. Aprovado em: 24/07/2014.

A parte da pesquisa em relação à morte deriva de monografia defendida em 2010 na Unifesp. Versões da parte sobre o sonho foram apresentadas em congressos em 2010 e uma prévia bastante resumida foi publicada na Revista de História da Biblioteca Nacional (n. 93, Junho de 2013). Gostaríamos de agradecer às contribuições feitas naquelas ocasiões pela audiência e pela banca, bem como também agradecemos a André Tavares, Evergton Sales Souza, Renato Cymbalista e aos pareceristas. A pesquisa contou com o apoio do CNPq e da Fapesp.

** Contato: Ifslima@unifesp.br.

***Contato: bianca.cpsilva@usp.br.
} 
meados do século XVIII. Se o jesuíta, mesmo antes de sua canonização em 1622 era entendido como Apóstolo do Oriente, a partir da segunda metade do século XVII, ocorreu uma mudança iconográfica pela qual aos personagens e elementos asiáticos somaram-se africanos e índios americanos na representação da cena de sua morte e de seus sonhos. Pretende-se a partir desse câmbio imagético analisar a construção de um programa visual da hagiografia de Xavier, no qual a vinculação exclusiva com o Oriente é suplantada pelos esforços em caracterizá-lo como exemplo máximo para a Missão, aplicável também - e sobretudo - às Américas. Interessam aqui em particular essas modulações no caso do Brasil e do Império Português.

Palavras-chave iconografia, São Francisco Xavier, Império Português

ABSTRACT This article analyzes pictorial interpretations of saint Francis Xavier's death and dreams visions, from early seventeenth century until mideighteenth century. If the Jesuit, even before his canonization in 1622, was seen as an Apostle of the East, a change occurred from the second half of the seventeenth century on. To the Asian iconographic indexes were added Africans and Native Americans ones in the depiction of his dreams and death. Through the observation of this imagetic shift the aim is to understand the making of a visual program for Xavier's hagiography, in which a prior and more exclusive relation with the East is surpassed by the efforts of fulfilling a role as the mission ultimate example, also - and specially - for the Americas. It particularly interests how these iconic displacements occurred in the case of the Portuguese Empire and Brazil.

Keywords iconography, Saint Francis Xavier, Portuguese Empire

\section{Introdução}

Santos máximos da Companhia de Jesus, Inácio de Loiola e Francisco Xavier foram canonizados no ano de 1622, junto a Teresa d'Ávila - os três responsáveis, de maneiras diversas, por uma nova religiosidade católica que foi difundida pela Igreja tridentina. Se Loiola era venerado como o fundador da ordem, Xavier era considerado o modelo máximo de missionário, traduzindo na sua figura os ideais da missão que marcavam a Companhia de Jesus: abnegação, trabalho, conversão, milagres, martírio. Um dos modos mais profícuos de propagar essa ideia era por meio das imagens seguindo, porém, as diretivas e preceptivas textuais e pictóricas determinados a partir de Trento. ${ }^{1}$ Constituindo, inventando e atualizando um programa visual, os

1 BORJA GÓMEZ, Jaime Humberto. Vásquez y el entorno de la pintura barroco. In: TOQUICA, Constanza (org.). El ofício del pintor: nuevas miradas a la obra de Gregorio Vásquez. Bogotá: Ministério de Cultura, 2008, p.35-39. 
episódios da biografia de Xavier foram traduzidos em óleos, afrescos, gravuras e desenhos ao longo dos séculos XVII e XVIII. Circulavam em livros, panfletos e folhetos volantes; ornavam as igrejas dos jesuítas em Roma, Goa, México, Luanda, Lisboa, Salvador. Em Salvador, ganhavam destaque porque, além de exemplo de missionário jesuíta, o santo era padroeiro da capital do Estado do Brasil desde 1686, e suas imagens integravam os esforços para tornar a devoção ao padroeiro efetiva. ${ }^{2}$ Xavier estava assim ligado direta e fisicamente, pela materialidade dos templos e pela visualidade das pinturas, aos espaços do Império Português, significando a união entre a Companhia e o Reino, entre Igreja e Monarquia.

A vida de Xavier (1506-1552), transcorrida entre Europa e Ásia, foi desta maneira transladada também pela representação visual para a América. Apóstolo do Oriente, missionário na Índia (1542-1545, 1548-1549), em Malaca (1545-1546, 1547), nas Molucas (1546), na China $(1549,1652)$ e no Japão (1549-1551), sua biografia traduzia-se na possibilidade da conversão dos gentios. Os episódios emblemáticos de sua vida, escolhidos a dedo pelos biógrafos e narrados em tinta e buril pelos pintores e gravadores, deviam servir para inspirar e educar qualquer fiel ou converter qualquer gentio no Império Português. As cenas selecionadas, em geral, narravam sua preparação para a ordenação e viagem para o Oriente, repleta de visões e sonhos proféticos; os tormentos sofridos na viagem, com seus milagres para que fossem superadas as dificuldades; o seu trabalho missionário e a derrota do gentilismo na Ásia, confirmando as profecias e corroborando os milagres; para, finalmente, ter a consagração da sua vida de sofrimento e dedicação na sua morte na costa chinesa, com a posterior devoção e maravilhas feitas pelo depois santo. ${ }^{3}$ Esse percurso, condensado em algumas dezenas de cenas, sintetizava não só a vida de Xavier mas os princípios do que deveria ser uma vida cristã segundo os jesuítas. Dentre essas várias cenas exemplares, pretendemos analisar aqui dois elementos do ciclo iconográfico de Xavier: a morte e os sonhos. Neles identificamos, em certa medida, nem tanto uma síntese do programa visual xavieriano, mas sobretudo dois epítomes da translação visual do Apóstolo do Oriente para o Ocidente, e mais do que isso, da sua ligação com as Américas, em especial, com os domínios americanos do Império Português.

2 Ver: SOUZA, Evergton Sales. Entre vênias e velas: disputa política e construção da memória do padroeiro de Salvador (1686-1760). Revista de História, v.162, 2010; SOUZA, Evergton Sales. São Francisco Xavier, padroeiro de Salvador: gênese de uma devoção impopular. Broteria Revista de Cultura, v.163, 2006.

3 Cf. CSATKAI, André, Beiträge zu den mitteleuropäischen Darstellungen des Todes des heiligen Franz Xaver im 17 und 18. Jahrhundert. Acta historiae artium Academiae Scientiarum Hungaricae, v.15, p.293, 1969; SOUZA, Evergton Sales. São Francisco Xavier, padroeiro de Salvador. 


\section{Morte}

A tradição cristã possui uma história construída com base em uma narrativa de virtudes, violência, morte e superação: ela celebra a figura de um homem que reconhece como filho do Criador de todas as coisas, o qual, por amor à humanidade, sofreu grandes misérias, padeceu sob uma cruz e por fim, superou a morte, passando então a viver a "verdadeira vida" ao lado de seu pai. A missão dos homens e mulheres da terra seria seguir tal exemplo, com vistas a alcançar o mesmo fim glorioso situado além do espaço e do tempo terreno. Especificamente no culto católico, os indivíduos que reconhecidamente dedicaram suas vidas a seguir o exemplo de Cristo são aqueles que receberam o título de Santo. O primeiro registro da Igreja Católica de alguém assim considerado é o de Santo Estevão, que ainda no primeiro século da era cristã teria sido morto violentamente por judeus ao defender a palavra de Cristo (At 7-8). A ideia de uma morte por motivos semelhantes fundamentou ao longo dos primeiros séculos da cristandade o conceito de mártir, sendo que no mesmo período, inúmeros foram os casos de mártires igualmente santificados: esse era tido como "o caminho da perfeição e da purificação espiritual" . ${ }^{4}$ Todavia, pelo menos desde o século $\mathrm{XV}$, o martírio já era entendido no continente europeu sob outras faces além daquela: também tinha legitimidade como tal o sofrimento dos exemplares seguidores de Cristo, que fosse causado por doenças prolongadas ou por provações de diferentes tipos culminando na morte. ${ }^{5}$ Esse alargamento do conceito teria ocorrido pela maior escassez em território europeu de episódios como o daqueles martírios literais passados, aliada à relevância da existência destes para a história cristã. Servindo como referências de vida virtuosa, essas pessoas ocupavam um lugar privilegiado na religiosidade cristã e seus túmulos e locais de morte tornaram-se importantes espaços simbólicos de um território do sagrado, pois "foram os primeiros locais de culto dos cristãos, locais de contato entre o universo cotidiano e o sagrado, e o mundo dos vivos e o dos mortos, estruturando a própria noção de espaço público da cristandade". ${ }^{6}$ No caso da atuação dos jesuítas nos domínios portugueses, além de significar a consagração da ação de Xavier e de se constituir como sacrifício a ser almejado pelos irmãos mais novos da ordem, o martírio serviu, em certa medida, para construir um mapa da missão, marcando espacialmente sua presença no orbe, ao mesmo tempo

4 RAMINELLI, Ronald. Imagens da colonização: a representação do índio de Caminha a Vieira. Rio de Janeiro: Zahar, 1996, p.77.

5 CYMBALISTA, Renato. Relíquias sagradas e a construção do território cristão na Idade Moderna. Anais do Museu Paulista, São Paulo, v.14, n.2, p.11-50,2006. cf. CYMBALISTA, Renato. Sangue, ossos e terras: os mortos e a ocupação do território luso-brasileiro. São Paulo: Alameda, 2011, p.34.

6 CYMBALISTA, Renato. Relíquias sagradas e a construção do território cristão na Idade Moderna. 
que as relíquias dos mártires traziam prestígio simbólico às localidades que os possuíssem. ${ }^{7}$

Xavier não padeceu por morte violenta em defesa de sua fé. Os relatos entretanto descreveram seus últimos momentos, em 1552, como dias passados em agonia, após dez anos de evangelização em regiões da Índia, China e Japão. Voltando do Japão em direção à China, adoentado, o jesuíta acabou deixado para morrer na ilha de Sancham, pouco habitada, abrigado numa choupana, quase sozinho, acompanhado somente por um chinês convertido, Antônio de Santa Fé, e um jovem oriental: morte sem enfrentamento direto mas em abandono em Cristo, intensamente referenciada e celebrada nas produções textuais e iconográficas posteriores. Descrição de sacrifício, paciência e abnegação do santo que simboliza o segundo entendimento do conceito de martírio. Houve, assim, uma construção hagiográfica da morte de Xavier, como momento que, ao imitar Cristo, exemplo máximo, deveria ser o ápice da vida santa. ${ }^{8}$

Isso se pode ver na Historia da vida do Padre Francisco Xavier que o também jesuíta João Lucena escreveu, impressa em Lisboa no ano de $1600,{ }^{9}$ dedicada à Duquesa de Bragança. Veiculada duas décadas antes de sua beatificação e canonização, foi uma das primeiras e mais notórias biografias do missionário, e base ao longo do século XVII para a imagem do santo no Império Português. ${ }^{10}$ Retratava a morte do "Mestre Xavier" em Sancham enfatizando os aspectos beatíficos e a analogia com Cristo:

Indo o mal muyto por diante, e sentindo o padre dos grandes balanços da nao, por Ihe impedirem com a fraqueza da cabeça a atençam as cousas divinas, pedio o leuassem a terra (...) onde o meteram [Antônio de Santa Fé e o oriental] (...) numa choupana (...). Era a choupana coberta de ramos, \& torrões, aberta per diuersas partes ao vento sem abrigo algum do frio (...). A esta conformidade com a pobreza, \& desamparo do bom lesu na morte, ajuntou o verdadeiro disipolo à imitaçam do sofrimento do mesmo Senhor. Por que nunca nos doze dias, que a infirmidade durou, Ihe ouviram palaura, nem enxergaram o menor sentimento (...) $\mathrm{Na}$ antemanhã de sabado seguinte dous de Dezembro, (...) com a imagem de Christo crucificado nas mãos, e nos olhos, \& com o mesmo Senhor no coraçam, \& na boca, chamando por lesu, \& Maria, até com as palavras meyas mortas, \& ja mais suspirando, que fallando, sayo do corpo aquella alma sãta, tam facil, \& suavemente, quam liure, \& desapegada andou sempre d'elle, \& deixando o com huma tam extraordinaria fermosura \& alegria no rosto (...) como

7 Ver: CYMBALISTA, Renato. Sangue, ossos e terras.

8 Isso era condizente com o ideal de Imitação de Cristo por todo fiel em seus atos cotidianos, nova atitude que era a marca da religiosidade "moderna" e cuja definição fez-se a partir do livro de ampla circulação e sucesso editorial de Tomás Kempis. Ver: CYMBALISTA, Renato, Sangue, ossos e terras, p. 34-35.

9 LUCENA, João de. Historia da vida do padre Francisco Xavier: e do que fizeram na India os mais religiosos da Companhia de lesu. Lisboa: Impressa per Pedro Crasbeeck, 1600.

10 E também para fora do território lusitano, tendo sido traduzido e impresso em italiano (Roma, 1613) e em espanhol (Sevilha, 1619). 
se ja começara a Ihe comunicar parte da gloria, a que esperamos a leuou logo a elle a diuina misericordia. ${ }^{11}$

Ao tratar da iconografia xavieriana a historiadora da arte Maria Gabriela Torres Olleta afirma que no século XVII havia duas atitudes gerais em relação à morte: uma "negativa y macabra" e, outra, "positiva y amable". ${ }^{12}$ A segunda tomava por objeto justamente a morte de santos, que era entendida como culminação e encontro. Assim, a morte "positiva y amable" apontava para a existência de uma convenção de caracterização dos gestos e beleza física daqueles personagens como sinal de santidade, dando seguimento a uma tradição hagiográfica que remeteria ao medievo,,$^{13}$ como presentes na narrativa de Lucena nos trechos destacados acima. Para Torres Olleta, a produção pictórica realizada especificamente em torno da morte de Xavier caracterizou-se, além desses qualificativos, pela composição da ambientação e de elementos pictóricos e iconográficos específicos: o traje de peregrino, a presença de orientais, de anjos e de objetos como o crucifixo, o rosário, a flor de açucena, livros, dentre outros signos, muitos deles remetendo ao Oriente. Isso poderia ser visto nas pinturas realizadas por artistas como Giovanni Battista Gaulli (Roma, 1672-1709), Carlo Maratti (Roma, 1625-1713), Benedictus Farjat (Roma?, 1646-1724) e Gaspar Conrado (México, século XVII). Essas composições de alguma maneira teriam derivado da forma estabelecida pelo francês Valerius Regnartius, autor de um ciclo de gravuras da vida e morte do missionário, elaboradas no âmbito das celebrações de sua canonização em 1622 e que se tornaram paradigmáticas. É a partir, não só das composições dos artistas nomeados acima, mas de um conjunto mais amplo de obras sobre a morte de São Francisco Xavier, ${ }^{14}$ que propomos que as produções pictóricas da morte de Xavier serviram para valorizar o papel da Companhia de Jesus não só na Europa e Ásia, onde ele atuou, mas também, paulatinamente, na América, onde nunca esteve. Esse leque de imagens permitiu-nos visualizar uma (re) elaboração dos elementos iconográficos envolvidos nas composições pelos quais se postulava a ressignificação de Xavier para essas partes ocidentais do orbe terrestre. A análise desse repertório iconográfico nos revelou uma possível periodização das formas de composição adotadas para o tema: um momento inicial em torno da primeira metade do século XVII, mais detidamente nos anos próximos à data de beatificação e canonização de Xavier $(1619,1622)$, seja como comemoração à sua elevação como beato

11 LUCENA, João de. Historia da vida do padre Francisco Xavier, p.893-194 (grifos nossos).

12 TORRES OLLETA, Maria Gabriela. Redes iconográficas: San Francisco Javier en la cultura visual del Barroco. Madri/Frankfurt: Iberoamerica/Vervuert, 2009, p.449.

13 TORRES OLLETA, Maria Gabriela. Redes iconográficas, p.409.

14 TORRES OLLETA, Maria Gabriela. Redes iconográficas; SILVA, Bianca Carolina Pereira. A presença da América nas representações iconográficas de São Francisco Xavier, Apóstolo do Oriente (século XVII). Guarulhos: Universidade Federal de São Paulo, 2010 (História, Monografia de bacharelado). 
e depois santo, seja como divulgação de que Xavier (assim como Loiola) entrara no panteão hagiológico do catolicismo; outro, a partir da segunda metade do mesmo século (mais propriamente em torno da década de 1660), num esforço de missionação dos jesuítas em termos globais. ${ }^{15}$

Duas séries importantes do primeiro momento são os ciclos produzidos por Regnartius (1622), já mencionado, em 18 gravuras em buril impressas em Roma por conta das comemorações ao santo na igreja II Gesú, ${ }^{16}$ e de André Reinoso (por volta de 161917), em 20 óleos sobre painel na sacristia de São Roque em Lisboa, ambas feitas com base nos escritos dos primeiros biógrafos de Xavier. ${ }^{18}$ Vale dizer que Roma e Lisboa tiveram as principais celebrações nessas ocasiões, contando com a mobilização de grandes aparatos e presenças de reis e nobres. As duas séries, entretanto, têm diferenças quanto, não só à técnica (gravura e pintura), mas também a sua possível intenção de circulação e recepção, pois a primeira fora pensada para ser distribuída como guia iconográfico e representação emblemática da vida do santo, e a segunda inserida num aparato luxuoso e fixo que mobiliava a sacristia da igreja dos jesuítas em Lisboa, a qual, em geral, só os padres tinham acesso. Uma pensada como objeto de estímulo devocional a um número maior de cristãos, divulgando um programa visual montado pelas festas na igreja jesuíta de Roma; outra, de circulação mais restrita, concebida, talvez, para reforçar, por meio do exemplo imagético de Xavier, os valores centrais da ordem e da missão jesuítica na própria imaginação'19 dos soldados de Cristo, nos momentos anteriores à pregação passados num ambiente contíguo ao púlpito e ao altar do templo da Companhia em Lisboa. Não obstante, para alguns autores como Vitor Serrão, ressaltando a função das sacristias seiscentistas como pinacotecas, teria sido o ciclo produzido na oficina de Reinoso que estabeleceu o padrão iconográfico da vida do santo em terras lusas, apesar de encontrarmos, como salienta Olleta, muitas composições posteriores que remetem, de modo mais

15 Em artigo sobre a iconografia da morte de Xavier na Hungria (e em parte da Europa Central) de finais do século XVII até finais do XVIII, Csatkai identificou três versões da cena na choupana: sozinho, com o navio ao fundo, e três querubins acima do corpo; com Antônio de Santa Fé e o jovem indiano; com um grupo mais vasto, composto por europeus sobretudo, venerando-o em seus últimos momentos, inspirado, segundo o autor, no óleo de Maratti. Ainda que Csatkai não mencione, a primeira versão segue bastante de perto o exemplar de Regnartius. Os outros dois poderiam ser localizados com a segundo período por nós identificado. Entretanto, os exemplares analisados no artigo não permitem uma periodização. CSATKAI, André, Beiträge zu den mitteleuropäischen Darstellungen des Todes des heiligen Franz Xaver im 17. und 18. Jahrhundert.

16 OSSWALD, Cristina. S. Francisco Xavier no Oriente: aspectos de devoção e Iconografia. In: SANTOS, Zulmira (org.) São Francisco Xavier nos 500 anos do nascimento de São Francisco Xavier. Porto: FLUP/CIUHE, 2007, p.123.

17 Essa datação é de Vitor Serrão (SERRÃO, Vitor. A lenda de São Francisco Xavier pelo pintor André Reinoso. Lisboa: Quetzal/Santa Casa de Misericórdia, 1993), embora Torres Olleta (Redes iconográficas, p.173) tenha levantado argumentos contrários, propondo uma datação posterior, mais perto da canonização, em 1622.

18 TORRES OLLETA, Maria Gabriela. Redes iconográficas, p.108-132, p.173-207; SERRÃO, Vitor. A lenda de São Francisco Xavier pelo pintor André Reinoso; ITURRIAGA ELORZA, Juan. Hechos prodigiosos atribuidos a San Francisco Javier en unos grabados del siglo XVII. Principe de Viana, ano 53, n.203, p.467-511, 1994.

19 Imaginação aqui pensada como potência que faz conhecer por imagens. Ver: JORDAN ARROYO, Maria. Da imaginação à imagem: o sonho como criação na Espanha do Siglo de Oro. In: FURTADO, Júnia. Sons, formas, cores e movimentos na Modernidade Atlântica: Europa, Américas e África. São Paulo: Annablume, 2008 
evidente, à série de Regnartius (a exemplo dos trabalhos em prata de seu túmulo em Goa). ${ }^{20}$ De qualquer modo, como tinham por base narrativas hagiográficas relativamente próximas e os momentos exemplares da vida (e morte) do santo foram estabelecidos de modo mais ou menos constante mesmo antes (e por causa, talvez) do processo de beatificação, os episódios representados por Regnartius e Reinoso são similares, e mesmo as escolhas pictográficas são próximas, sendo necessário atentar aos detalhes para identificar as particularidades e, talvez, pensar os programas visuais daquele primeiro momento. Isso fica evidente ao olharmos para como foi retratada a morte em ambos.

Regnartius representou a imagem do missionário em seus últimos momentos, sozinho em uma cabana com uma paisagem bucólica ao fundo à direita, seu corpo tranquilo, deitado, e invocando o nome de "Jesus Maria" segurando uma cruz. O óleo de Reinoso (FIGURA 1) apresenta disposição semelhante, ainda que invertida, porém incluindo mais elementos e ampliando a narrativa. A começar há a presença do próprio Cristo e da Virgem Maria e uma corte angelical no canto superior esquerdo. No fundo à esquerda, abaixo dos anjos, mostra a narrativa de episódios da vida de Xavier anteriores ao momento de sua morte: a paisagem marítima com o navio português em que navegava, o desembarque na ilha que seria seu destino final e a presença de dois homens, provavelmente o chinês Antônio e o jovem oriental. Descrição que remete ao texto de João de Lucena, especificamente utilizado pelo artista, segundo Vitor Serrão. ${ }^{21}$ Assim, guardado o contexto de produção das duas obras e as diferentes caracterizações iconográficas que contêm, ambas, especialmente em Reinoso, mostram um padrão que remete à missão evangelizadora do jesuíta realizada em regiões do Oriente, colado à narrativa do momento de sua morte mais solitária, beatífica e serena.

20 SERRÃO, Vitor. A lenda de São Francisco Xavier pelo pintor André Reinoso; TORRES OLLETA, Maria Gabriela. Redes iconográficas, p.128, p.259; Sobre as séries de Goa, ver também: OSSWALD, Cristina. S. Francisco Xavier no Oriente: aspectos de devoção e Iconografia, p.123. Sobre a questão das sacristias como espaço de propaganda, ver também: SOBRAL, Luis de Moura. Espiritualidade e propaganda nos programas iconográficos dos Jesuítas Portugueses. In: A Companhia de Jesus na Península Ibérica nos sécs. XVI e XVII: espiritualidade e cultura: actas. Porto: FLUP, 2004, esp. p.400-415; SOBRAL, Luis de Moura. Pintura, santos y propaganda: la sacristía del antiguo colegio de los jesuitas de Salvador, Bahia. In: ARANDA, Ana María; GUTIERREZ, Ramón; MORENO, Arsenio; QUILES, Fernando (ed.). Barroco Iberoamericano: territorio, arte, espacio y sociedad. v.1, Sevilha: Giralda, 2001, p.393-403.

21 SERRÃO, Vitor. A lenda de São Francisco Xavier pelo pintor André Reinoso. 


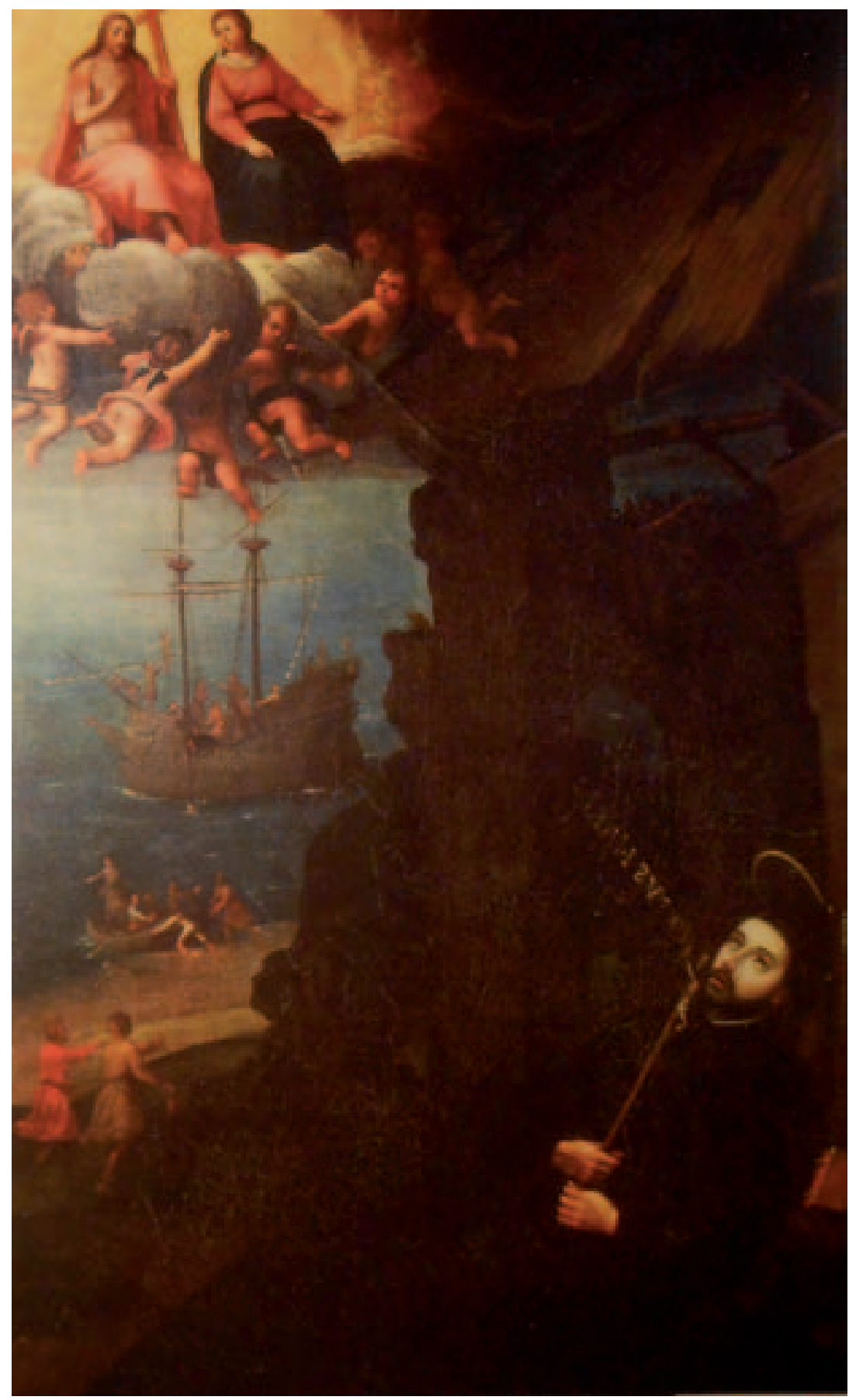

Figura 1

REINOSO, André. Morte de São Francisco Xavier. c. 1619.

Óleo sobre tela, Sacristia da Igreja de S. Roque, Lisboa. 
Num segundo momento de composição iconográfica, destacamos as produções pictóricas de artistas como Giovan Battista Gaulli, chamado Baciccio (Roma, c. 1676, e Ascoli Piceno, c. 1670-1680), Ciro Ferri (Roma, c. 1670), (Figura 2) e Carlo Maratti (Roma, 1679). ${ }^{22}$ Baciccio, Ferri e Maratti eram artistas que pertenciam aos círculos de patronato artístico da ordem em Roma e, ainda que Carlo Maratti tivesse muito maior prestígio, disputavam, com outros pintores, escultores e arquitetos, as encomendas para decorar os templos da ordem na cidade santa nas décadas de 1670 e 1680. Maratti, Ferri e Baciccio junto a Giacinto Brandi foram considerados para serem comissionados com as pinturas que decorariam a reforma da igreja II Gesù, templo central da Companhia. Levadas a frente pelo geral da Ordem, Gian Paolo Oliva, com apoio da família Farnese, as comissões de pinturas para II Gesù (e também para Sant'Andrea il Quirinale) implicaram, em alguma medida, uma renovação do programa visual da companhia. Gaulli ficou encarregado dos afrescos do templo central, bem como do altar de Xavier em Sant'Andrea, com três óleos, um de um sermão, outro de um batismo e, por fim, a morte do santo. Em 1674, Maratti foi escolhido para o altar de Xavier em II Gesù e, quando pronto, em 1679, seu óleo da morte do jesuíta substituiu a tela de Anthony Van Dyck, colocada quando da festa de canonização em 1622. Ferri, ao que parece, foi preterido em todas os certames. ${ }^{23}$ As obras seguem apresentando a composição do santo agonizante baixo a simples cabana, em um plano alto de onde ao fundo se nota a paisagem marítima (com a presença da nau, de forma mais discreta que na obra anterior), seres angelicais, tipos não religiosos e os demais objetos costumeiros, como o crucifixo e o livro. Essa composição, não muito longe da tela de Reinoso ou da gravura de Regnartius, permanecia como um padrão importante ainda na segunda metade do século XVII, a ver pelo óleo de Gaulli em Sant'Andrea, ${ }^{24}$ de cerca de 1676, inclusive copiado e divulgado por meio de gravuras que depois serviram de base a pinturas americanas. ${ }^{25}$ Porém, as pinturas de Ferri e Maratti bem como um outro óleo do Baciccio, na comuna de Ascoli Piceno, tinham não só uma

22 Giovan Battista Gaulli, chamado Baciccio. Morte de São Francisco Xavier. c. 1676, Óleo sobre tela, Igreja de Sant'Andrea il Quirinale, Roma; Giovan Battista Gaulli, chamado Baciccio. Morte de São Francisco Xavier. c. 1676, Óleo sobre tela, Igreja de Santo Agostinho, Ascoli Piceno, Itália; Ciro Ferri. Morte de São Francisco Xavier. c. 1670. Óleo sobre tela, Roma; Carlo Maratti. Morte de São Francisco Xavier. 1679. Óleo sobre tela, Altar da Il Gesù, Roma.

23 HOOD, William. Ciro Ferri's pensiero for the altarpiece of the blessed Stanilaus Kostka in Sant'Andrea il Quirinale. Allen Memorial Art Museum Bulletin, v.37, n.1, 1979-1980, p.26-50; HASKELL, Francis. Mecenas e pintores: arte e sociedade na Itália barroca. São Paulo: EDUSP, 1997, p.134-137, p.144, p.148.

24 HOOD, William. Ciro Ferri's pensiero for the altarpiece of the blessed Stanilaus Kostka, p.42-44.

25 Ver: KILIAN, Bartholomäus, (a partir de Giovanni Battista Gaulli). Conclusiones Philosophicae, 1685, gravura em metal, Museu Britânico, Londres, Inglaterra; FARJAT, Benoît Farjat. S. Franciscus Xavierius Soc. lesu Indiarum Apostolus. c. 1670, gravura em metal, Museu Britânico, Londres, Inglaterra; Escola de Lima. Morte de São Francisco Xavier. Século XVIII, óleo sobre tela, Catedral de Lima, Peru; VÁSQUEZ, Gregorio. Morte de São Francisco Xavier, antes de 1711, óleo sobre tela, Col. Privada, Bogotá, Colômbia. Para as pinturas americanas e a comparação com as gravuras, ver base de dados do Project on the Engraved Sources of Spanish Colonial Art (PESSCA), disponível em: http://colonialart.org/archive/artList?row=168\&col=934a-936b. Acesso em: 10 jan. 2013. 
nova disposição dessas figuras, como alguns novos elementos que para nós são bastante significativos.

Nessas representações aparecem em companhia de São Francisco Xavier não somente os dois asiáticos, como os relatados por Lucena, presentes ao fundo, como detalhe narrativo, na produção de Reinoso, mas sim, um grupo de pessoas com algum destaque. Estas aparecem em posição de contemplação e desalento em vista da morte do missionário, sendo caracterizadas com trajes distintos que traduzem visualmente não só uma diversidade de status social como também de origens culturais. Alguns portam elaborados trajes coloridos e/ou sobreposição de tecidos à maneira oriental, com certo luxo aparente, ${ }^{26}$ outros, panos menos elaborados, com vestes simples. Dentre estes últimos, identificam-se o uso de elementos que remetem aos tipos originários não do Oriente, mas do continente americano.

A referência ameríndia está presente tanto nas obras de Gaulli, Ferri (FIGURA 2) e Maratti. ${ }^{27}$ Mostram tipos físicos robustos, de pele mais escura, seminus, que levam consigo adornos ou instrumentos como cocares de penas, borduna, ou arco e flechas. Caracterização de uma tipologia ameríndia que encontra eco nas produções textuais dos cronistas e viajantes que produziram relatos e demais escritores que tomaram o Novo Mundo como objeto, bem como nas imagens pictóricas elaboradas acerca destes povos. ${ }^{28}$

Torres Olleta também faz algumas menções com relação ao emprego destes índices ameríndios nas produções xavierianas, quando trata, por exemplo, de uma série romana setecentista de gravuras com função pedagógica. Ao descrever uma cena na qual se representava um conflito entre parabas - convertidos - e baragas - povos orientais resistentes à nova fé -, aponta que a caracterização dos baragas levava, dentre outras coisas, "plumas al estilo americano", em "una curiosa mezcolanza iconográfica que no obedece a imperativos de ningún realismo, sino al sentido simbólico y pedagógico". Em relação à outra imagem, da mesma série, na qual aparece "un indio americano tropical, emplumado y semidesnudo", a autora considera que esta seria uma "incoherencia procedente de la mezcla de motivos iconográficos". ${ }^{29}$ Operava-se a superação de elementos biográficos que constituíram a hagiografia do Apóstolo do Oriente - a presença de Xavier no

26 Sobre panos como signo do oriente e de luxo e riqueza na pintura, ver: BROTTON, Jerry. O Bazar do renascimento: da rota da seda a Michelangelo. São Paulo: Grua Livros, 2009.

27 Os desenhos prévios às pinturas de Maratti e Ferri têm diferenças entre si no que se refere aos personagens ameríndios. No desenho preparatório de Ferri, os índios estão já lá presentes, enquanto que em um estudo inicial de Maratti, os expectadores da sua morte na terra são poucos (dois, como no relato de Lucena) e a corte celestial muito maior. FERRI, Cito. Morte de São Francisco Xavier. Antes de 1670, desenho s $\backslash$ papel, Metropolitan, Nova York, EUA; MARATTI, Carlo. Primo pensiero dì mano del Celebre Pittar Carlo Maratta fatto per la Tavola d'Altare di S. Francesco Saverio da lui dipinta nella Chiesa del Giesù in Roma. c. 1674-1679, desenho s\ papel, Museu Britânico, Londres, Inglaterra.

28 RAMINELLI, Ronald. Imagens da colonização.

29 TORRES OLLETA, Maria Gabriela. Redes iconográficas, p.169, p.171. Personagens com cocares plumados aparecem também numa gravura de uma série seiscentista ao retratar o mesmo episódio: GOETIERS, A. S. Xaverius Bagadarum exercitum in neophytos ruente cruce profligat. Gravura em metal, 1652-1686, Holanda. 


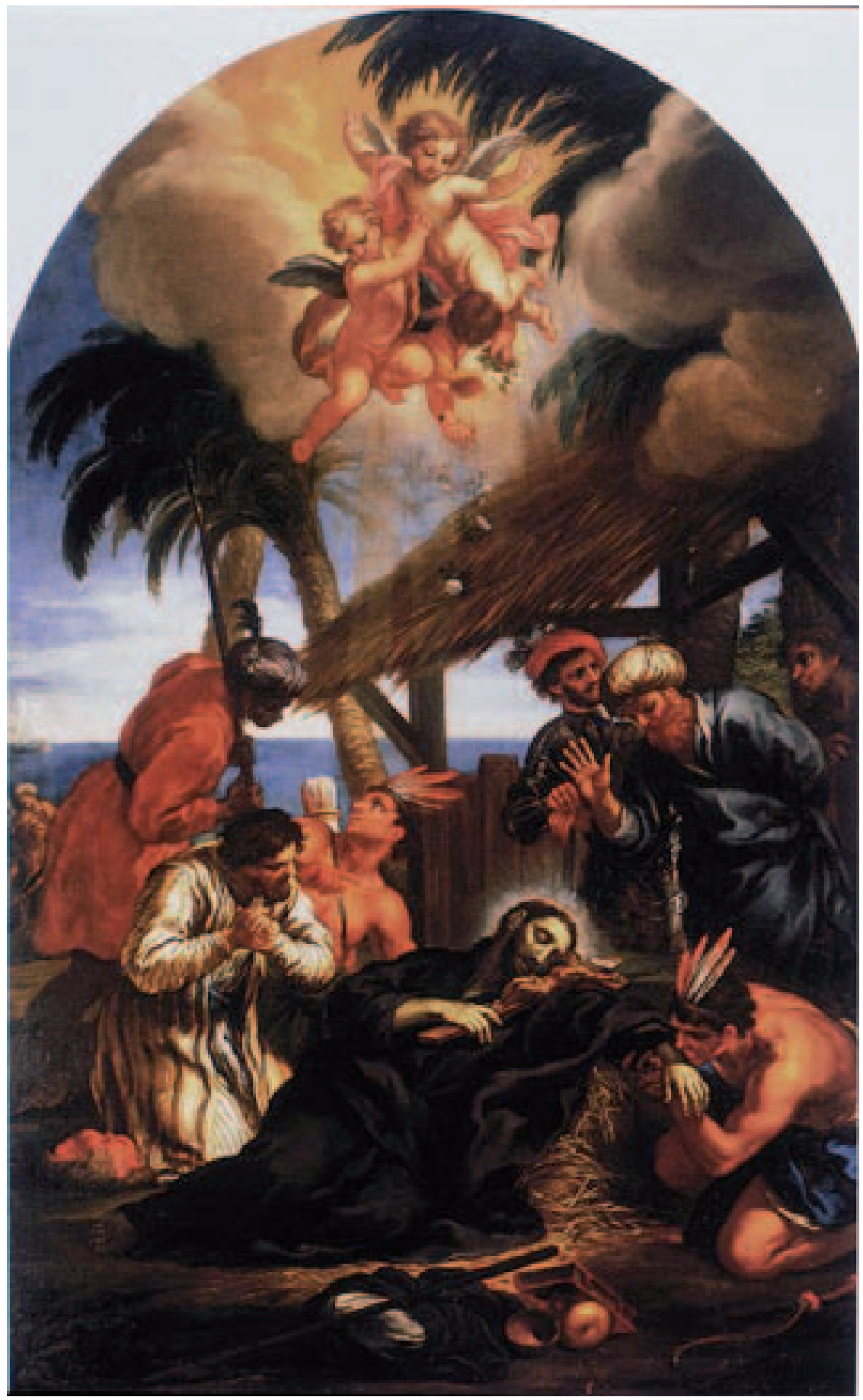

Figura 2

FERRI, Ciro. Morte de São Francisco Xavier. c. 1670. Óleo sobre tela, Roma. 
Oriente - em direção a um redimensionamento da experiência catequética ao ampliar imageticamente a atuação missionária e marcar sua presença e ligação com outras partes do globo. Como analisa a mesma autora, ao tratar de representações mexicanas de Xavier batizando reis etíopes, japoneses e mesmo o próprio Montezuma, o discurso que se constrói ao se superar tal limite geo-biográfico é o do santo como um "evangelizador universal". ${ }^{30}$

Interessante observar ainda que as imagens destacadas nessa segunda composição iconográfica parecem apontar não só para a mudança de uma biografia ligada ao Oriente ao incorporar referências a índios americanos, mas também agregar um novo repertório na construção do programa visual do santo jesuíta pela própria maneira como dispõe estes e outros personagens no espaço que circunda o santo. A maneira como são incorporados em meio à cena do santo agonizante/morto em um abrigo simples parece remeter à forma clássica utilizada para a composição do nascimento do próprio Cristo; mais especificamente, o episódio da Adoração dos três Reis Magos.

Na tradição católica o caso dos três Reis Magos se refere à mobilização dos que seriam representantes de diferentes lugares da terra, para reverenciar aquele que se acreditava como digno da mais profunda adoração. Um reconhecimento de todo o orbe com relação à figura do recém-nascido e de tudo o que ele significava: a anunciação de uma verdadeira fé, a qual todos deviam se render. Como os três emblematizavam, em certa medida, as regiões do mundo conhecido que vinham ver a boa nova, com o descobrimento da América no final do século XV, não tardou para que surgissem representações pictóricas do tema incluindo a América. Como destaca Raminelli, ${ }^{31}$ logo após a chegada dos portugueses às costas do Novo Mundo, Grão Vasco compõe uma visita dos Reis Magos empregando elementos vinculados a uma iconografia ameríndia em constituição (penas, plumas, cocares, pele avermelhada) para representar um dos reis: a América, assim, também se rendia àquela fé. Desta maneira, se considerarmos que o tema da morte xavieriana seguiu esta mesma lógica na obra dos artistas mencionados, ${ }^{32}$ podemos estabelecer a relação da aproximação do santo com a própria figura do Cristo, não só por ter seguido o seu exemplo, mas por representar uma verdade a ser observada em todo o mundo. Inclusive, essa lógica de representação significaria em si mesma o fechamento de um ciclo: nascimento e morte, natal e páscoa em uma só cena. Ou ainda, o

30 TORRES OLLETA, Maria Gabriela. Redes iconográficas, p.121.

31 RAMINELLI, Ronald. Imagens da colonização, p.152.

32 Destacamos que Maratti, foi conhecido por retratar temas religiosos dentre os quais encontramos cenas da Adoração ao Cristo recém-nascido (Adoração dos Magos, óleo sobre tela, déc. 1650, Hermitage, São Petersburgo, Rússia; Adoração dos pastores, óleo sobre tela, c. 1690, Hermitage, São Petersburgo, Rússia). A familiaridade do autor com esse tema iconográfico reforça a hipótese de que sua composição da morte xavieriana possui certa proximidade com tal padrão. SILVA, Bianca C. P., A presença da América nas representações iconográficas de São Francisco Xavier, p.39. 
renascimento na morte, pelo qual o santo viveria finalmente no além aquilo pelo qual tinha morrido: estar com Cristo desfrutando da "verdadeira vida".

Sendo Xavier uma das figuras de maior destaque da Companhia de Jesus (seu co-fundador e exemplo máximo de missionário), ao se assemelhá-lo ao próprio Cristo de maneira tão elevada e próxima, poderia servir como suporte de um discurso de (re)valorização da ordem nas regiões representadas, do Oriente ao Ocidente. Na segunda metade do século XVII - ao mesmo tempo em que Cerri, Maratti, Baciccio e outros artistas elaboravam suas composições da morte de Xavier -, os jesuítas enfrentavam grandes dificuldades de acesso e permanência em regiões do Oriente, decorrentes das tensões dos portugueses (seus aliados) tanto com poderes locais, quanto com as pretensões coloniais holandesas na altura da União Ibérica, em guerra com a coroa espanhola e, por decorrência, com o Império Português. Após a Restauração, perdidas quase todas as praças na Ásia, uma saída para a coroa de Portugal foi fortalecer seu poder na América e esse movimento para o Ocidente seria acompanhado pelos religiosos da Companhia. ${ }^{33}$

Mesmo na América de colonização espanhola, pudemos identificar uma produção e circulação de imagens de Xavier entre os séculos XVII e XVIII, que indicam um esforço de trazer seu exemplo para o Novo Mundo. Parte delas se constitui pelos ciclos pictóricos dispostos em igrejas da Companhia em países como Peru (San Marcelo de Lima, oito imagens, c. 1610), Chile (Convento del Carmen de Santiago, sete imagens, séculos XVII-XVIII), México (Puebla, 14 imagens distribuídas em três igrejas, séculos XVII-XVIII), Equador (La Merced de Quito, 30 quadros, século XVIII). ${ }^{34}$ Estas seguem os padrões de composição europeus para os temas xavierianos, sugerindo a circulação de imagens entre os dois continentes, provavelmente pelas gravuras. Mas ao mesmo tempo, é possível identificar em algumas delas a adaptação para o ambiente americano, como no caso das obras de Quito em que aparecem cabelos, penteados, adornos mais próximos à realidade equatoriana e, inclusive, o tipo ameríndio incorporado especificamente em uma tela da morte de Xavier - o que poderia ser ao mesmo tempo assimilação de uma iconografia existente na Europa e adaptação à localidade do artista. Além dos ciclos pictóricos, encontramos outros dois óleos que tratam do tema da morte do santo no século XVII, ambos realizados por pintores importantes e profícuos à época da América espanhola: um do neogranadino Gregório Vazquez, de 1668, hoje no Museu de Arte Colonial, em Bogotá, ${ }^{35}$ e outro atribuído ao Gaspar Conrado, atuante em Puebla,

33 BOXER, Charles Ralph. O Império marítimo português 1415-1825. São Paulo: Companhia de Letras, 2006; ALDEN, Dauril. The making of an enterprise. Stanford: Stanford University Press, 1996, cap.7.

34 TORRES OLLETA, Maria Gabriela. Redes iconográficas, p.221-258.

35 BORJA GÓMEZ, Jaime Humberto. Vásquez y el entorno de la pintura barroco, p.40, p.42. 
México ${ }^{36}$ Seguem, em certa medida, os padrões iconográficos europeus e trazem uma corte de anjos à espera do santo nos céus. A tela de Conrado, contudo, retrata de maneira destacada os traços orientais de Antônio de Santa Fé, que acompanhara Xavier até o momento de sua morte. Trata-se de um artista da Nova Espanha que, desde a América, ressalta o valor do santo no Oriente, indicada na caracterização chinesa do personagem que assiste a morte do jesuíta. Na mesma Puebla, na igreja de Nossa Senhora da Luz, o tema se repete. ${ }^{37}$ Assim, no México, no Novo Mundo, Xavier morre cercado por figuras orientais; na Europa, no Velho Mundo, por figuras ameríndias.

No caso da América portuguesa, as referências xavierianas dirigemnos mais especificamente para a cidade de Salvador, capital do Estado do Brasil até 1763. Foi em Salvador que o jesuíta Antônio Vieira redigiu o volume Xavier Dormindo e Xavier Acordado, que saiu como o oitavo tomo dos seus sermões, composto por 15 prédicas, três baseadas em sonhos do santo, e 12 representando, como num ciclo pictórico, os momentos da vida e das virtudes de Xavier. Neles, Xavier é referenciado por Vieira como o maior de todos os santos, chegando mesmo a se equiparar pela qualidade de sua obra - e não em essência, pois somente humano - ao próprio Cristo, modelo último de santidade dos quais os outros só podiam ser figuras. Sermões nunca pregados, foram impressos em 1694 enquanto resposta à demanda da rainha portuguesa, Maria Sofia de Neuburgo, devota de Xavier. ${ }^{38}$ Além dos quinze sermões da oitava parte, Vieira ainda dedicou ao santo, na sequência à impressão de Xavier Dormindo e Xavier Acordado, um sermão gratulatório pelo nascimento do quarto filho de Maria Sofia e Pedro II, impresso no tomo XI dos seus Sermoens. ${ }^{39}$ Mesmo antes, num sermão de Ação de Graças (1688), ${ }^{40}$ Xavier ocupou papel central por ser considerado pela rainha o responsável pelo nascimento do primeiro filho do casal real, ainda que este viesse a morrer logo em seguida. ${ }^{41}$ Mas vale lembrar que não só a rainha, de origem alemã, era devota do santo; toda a casa de Bragança o era, mesmo quando ainda uma casa ducal em inícios do século XVII, a tomar como exemplo a dedicatória da biografia de Xavier para a duquesa Catarina. Também era relevante a ligação estreita entre a

36 OSSWALD, Cristina. S. Francisco Xavier no Oriente, p.139

37 TORRES OLLETA, Maria Gabriela. Redes iconográficas, p.229, p.658 - fig.205.

38 VIEIRA, Antônio. Xavier dormindo, e Xavier acordado: dormindo em tres Orações Panegyricas no Triduo da sua Festa Dedicadas aos tres principes que A Rainha Nossa Senhora confessa dever à intercessão do mesmo Santo, Accordado, Em doze Sermoens Panegyricos, Moraes, \& Asceticos, (...). Oitava Parte. Lisboa : Officina de Miguel Deslandes, 1694. cf. LIMA, Luís Filipe Silvério. Padre Vieira - sonhos proféticos, profecias oníricas: o tempo do Quinto Império nos sermões de Xavier Dormindo. São Paulo: Humanitas, 2004, cap.2 e 3; ALMEIDA, Isabel. Um pé na terra, outro nas estrelas: a propósito de S. Francisco Xavier nos Sermoens de Vieira. Brotéria, 5/6, v.163, p.395-415, 2006.

39 VIEIRA, Antônio, Sermoens do P. Antonio Vieira da Companhia de Jesu, Prègador de Sua Magestade. Undecima Parte, offerecida à Serenissima Rainha da Grã Bretanha. Lisboa: Officina de Miguel Deslandes, 1696, p.512-540.

40 VIEIRA, Antônio. Palavra de Deos empenhada, e desempenhada: Empenhada (...). Lisboa: Officina de Miguel Deslandes, 1690, p.98 pass.

41 LIMA, Luís Filipe Silvério. Sonho e missão em padre Vieira. In: WV.AA. Vieira: vida e palavra. São Paulo: Loyola, 2008; ALMEIDA, Isabel. Um pé na terra, outro nas estrelas. 
figura de Xavier e a coroa portuguesa já desde o século XVI, fortalecida no século XVII. Tanto a trajetória do jesuíta (que partira para o Oriente de Portugal, com a bênção de João III) quanto sua devoção (que se vinculava a eventos importantes do reino, como a Restauração de 1640, do qual era considerado padroeiro pela proximidade do $1^{\circ}$ de dezembro, data da Restauração, de sua festa, 3 de dezembro) foram pensadas muitas vezes de modo indissociável da expansão dos domínios portugueses, da conquista do Oriente e da conversão dos gentios, unindo os jesuítas a Portugal. ${ }^{42}$

Na mesma altura da escritura dos sermões de Vieira, Xavier foi representado em Salvador no programa iconográfico da sacristia da igreja jesuíta da cidade, onde então funcionava o colégio da Companhia. De acordo com Luis de Moura Sobral, a sacristia e capela da hoje conhecida como Catedral Basílica de Salvador foi, entre 1683 e 1694, objeto de muito cuidado para os membros da Companhia de Jesus. Recebia naquele momento uma decoração condizente com o programa iconográfico já implantado em outras de suas casas pela Europa, pela Ásia e mesmo pela América: quadros que representavam além dos temas cristológicos e marianos, seus próprios membros. Uma política iconográfica que visava à glorificação da Companhia e que era empregada progressivamente desde as mobilizações pela canonização de Inácio de Loiola no início do XVII. ${ }^{43}$ Eram 17 quadros bíblicos do Antigo testamento no alto das paredes, 21 painéis com figuras de jesuítas venerados expostos no forro, entre eles Xavier, 16 quadros com cenas da vida de Virgem Maria no espaldar dos dois arcazes e 18 telas sobre a vida de Cristo na Capela-mor. ${ }^{44} \mathrm{~A}$ decoração da capela central também era do século XVII. Trazia episódios da vida de Cristo, em painéis laterais ao altar, e no altar principal, o camarim para o Santíssimo Sacramento trazia na face externa de suas portas pintado Cristo em pé, segurando a cruz, e os dois santos jesuítas ajoelhados abaixo dele, Inácio, à sua direita, com paramentos litúrgicos, recebendo uma hóstia iluminada de Jesus, e Xavier, à sua esquerda em pose de reverência..$^{45}$ Vale notar que, embora a maior parte das pinturas seiscentistas referentes aos membros da ordem esteja concentrada no forro da sacristia, aparece esta tela, no meio da série dedicada à vida de Cristo, com a figura de Loiola e Xavier recebendo sua

42 MARQUES, João Francisco. A parenética portuguesa e a restauração. v.2, Porto: INIC, 1989, p.133; LIMA, Luís Filipe Silvério. Padre Vieira, p.91-96; ZUPANOV, Ines. A história do futuro: profecias móveis de jesuítas entre Nápoles, Índia e Brasil (século XVII). Cultura. Revista de História e Teoria das Ideias, v.XXIV, n.1, p.150-154, 2007.

43 SOBRAL, Luis de Moura. Espiritualidade e propaganda nos programas iconográficos dos Jesuítas Portugueses; SOBRAL, Luis de Moura. Pintura, santos y propaganda: la sacristía del antiguo colegio de los jesuitas de Salvador, Bahia. Para uma cronologia das obras e intervenções na antiga Igreja dos Jesuítas, baseamo-nos em LEITE, Serafim. História da Companhia de Jesus no Brasil. v.4, São Paulo: Loyola, 2004; PEREIRA, Sonia Gomes. Artistas e artífices da Catedral de Salvador, antiga igreja dos Jesuítas na Bahia. In: MARTINS, Fausto Sanches (coord.). Artistas e artífices e a sua mobilidade no mundo de expressão portuguesa. Porto: FLUP, 2005, p.483-493.

44 BRESCIANI, Carlos. Pinturas da Catedral Basílica de Salvador. Salvador: Colégio Antônio Vieira, 2006.

45 A autoria era provavelmente de outro irmão jesuíta, Domingos Rodrigues, ativo na segunda metade do seiscentos. BRESCIANI, Carlos, Pinturas da Catedral Basílica de Salvador, p.44. 
bênção. Embora os mártires e outros principais jesuítas do Brasil -inclusive, Anchieta - tivessem seus lugares na decoração da instituição, eram Loiola e Xavier as figuras que ganhavam destaque ao serem expostas não só entre estes, como também junto ao próprio Cristo.

Importa destacar que tais intervenções no colégio da Bahia estavam em andamento quando, em 1689, Xavier ganhou o status de padroeiro da cidade de Salvador. Desde alguns anos a população local vinha sendo dizimada por uma grave epidemia de febre amarela. Xavier, conhecido por operar curas em vida e mesmo depois de morto, foi eleito pela Câmara de vereadores e com apoio da arquidiocese como padroeiro da cidade, ganhando um dia de celebração no calendário local. Segundo Souza, a continuidade da epidemia apesar da eleição do santo protetor não teria incentivado os fiéis a cultuarem-no com muita dedicação. O grande dispêndio de dinheiro público em vista dos festejos do dia de Xavier que se seguiram nos anos posteriores seria mais um indício do compromisso da Câmara para com o seu voto e da influência da arquidiocese do que de um forte culto popular ao jesuíta. ${ }^{46}$ Para além do fato de ter sido pouco cultuado pelo povo de Salvador, o que cabe ressaltar neste momento é novamente a mobilização da Companhia de Jesus sobre sua figura, somada à atuação da Câmara e da arquidiocese, em particular no programa visual da Igreja dos Jesuítas em Salvador. Esse esforço continuou no século XVIII.

Levantadas entre 1745 e 1755, as capelas laterais de Inácio e Xavier reforçam a relação iconográfica presente nas portas do camarim seiscentista do altar central. As duas capelas ocupam o transepto, estando uma em frente à outra, e o arco era decorado com pinturas, de autoria provável de um irmão do colégio jesuítico baiano, o portuense Francisco Coelho, que contavam a vida dos santos homenageados. ${ }^{47} \mathrm{~A}$ capela à direita do altar-mor era dedicada a Loiola; à esquerda, a Xavier. Sua disposição na nave cria uma analogia entre a capela-mor e as duas laterais, entre Cristo e os santos fundadores, como duas faces complementares da ação da Companhia em seu serviço a Jesus, como presente na pintura no altar-mor. O espelhamento e complementaridade, entretanto, não se davam só pelo espaço e disposição na arquitetura da igreja, mas também porque as pinturas em painéis eram em mesmo número e dispostas de maneira similar. Xavier era face de Loiola, e ambos eram vértices inferiores e especulares de um triângulo que tinha seu pico em Jesus. Mas no que consistia a imagem de Xavier, duplo complementar de Loiola, servo ardoroso de Cristo, exemplo e fundador da ordem?

O altar dedicado a Xavier trazia no arco externo óleos com cenas da sua vida, eleitas entre algumas das que compunham as séries iconográfi-

46 SOUZA, Evergton Sales. Entre vênias e velas: disputa política e construção da memória do padroeiro de Salvador. 47 BRESCIANI, Carlos, Pinturas da Catedral Basílica de Salvador. 
cas anteriores, por meio do qual podemos pensar no que seria a imagem setecentista do santo na Bahia. Do lado esquerdo do altar, o exemplo do missionário e religioso, por meio de seus trabalhos e ações, começando pela apresentação de Xavier ao Bispo de Goa, depois no navio indo para o Oriente, se flagelando para expiar os pecados de possível convertido, por fim, batizando um príncipe oriental. Do lado direito, os episódios miraculosos e o fim almejado, a morte do jesuíta sendo assistido por Deus e sua corte celestial, o milagre da transformação da água do mar em água doce, o chamado "milagre do caranguejo", e o sonho do índio. No meio, no centro da abóboda, Xavier aos pés de Paulo III, acompanhado por Inácio, de certa maneira, reforçando o caráter apostólico e romano da companhia (perto de anos turbulentos para ela, note-se) lembrando aqui, no ato dos santos fundadores, sua obediência ao Papa, ao que os jesuítas dedicavam um voto específico em sua profissão solene. De um lado, a ação concreta (traduzida nos atos de obediência, perseverança, penitência, flagelação, conversão), exemplo que o fiel (e os jesuítas) deveriam escolher seguir; de outro, os milagres e sua morte abençoada, que confirmavam sua santidade mas também se faziam em relação aos seus trabalhos, que motivavam o expectador por meio da exaltação de sua figura beata. De certa maneira, seguiam em parte a própria construção dos sermões de Xavier dormindo, Xavier acordado, nos quais Vieira, segundo Cabral, misturava na sua pregação o estilo exornativo (exaltação dos feitos) e o deliberativo (ilustração moral). ${ }_{4}^{48}$

A composição atribuída a Coelho para o tema da morte xavieriana (Figura 3) também está de acordo com alguns elementos da tradição iconográfica estabelecida a partir dos artistas europeus: o jesuíta aparece com o corpo deitado no lado direito do primeiro plano do quadro, esboçando gestos direcionados para os ícones representativos da esfera divina, como sinal de sua passagem para a "verdadeira vida". Não obstante, diferente das obras anteriores, que contavam com a presença de cortes de seres celestiais e/ou de Cristo com sua mãe em um plano mais distanciado, aqui o divino está colocado, sobretudo, pela figura de um homem de fisionomia envelhecida e trajes suntuosos. Irrompendo dos céus com a presença de querubins, irradiado por luzes que partem do plano superior, das quais é ao mesmo tempo fonte de irradiação, ele dirige seu corpo e gestos para o agonizante quase o tocando. Este personagem ocupa a maior parte da tela, sem deixar espaço para a disposição de outras narrativas que fizeram parte de composições anteriores do tema, ou mesmo para a insinuação do simples abrigo final de Xavier, com seus recorrentes objetos (livro, crucifixo, etc.). As disposições do jesuíta igualmente possuem peculiaridades neste caso, pela complementaridade dos seus gestos para com a figura divina desde seu posicionamento inferior (uma das mãos espalmada e a outra

48 CABRAL, Luiz Gonzaga. Vieira-prègador. 2 ed. v.2, Braga: Cruz, 1936, p.405-409, p.420-421. 
levemente fechada; perna direita mais saliente baixo as vestes) e seu olhar desperto, atento, em vez de olhos semicerrados. Enfim, dado o contexto desta presença e sua incompatibilidade com a iconografia tradicional de Cristo (Filho), Xavier vê-se diante do próprio Criador (Pai) na pintura de Salvador. Mas o que isso poderia significar? Parece-nos possível pensar que fosse uma referência à própria ideia da equiparação da figura de Cristo pelo jesuíta, presente no sermão de Vieira. Sendo assim, na hora de sua morte recebeu o socorro de Deus, tal como teria clamado o próprio Cristo no momento de sua crucificação. ${ }^{49}$

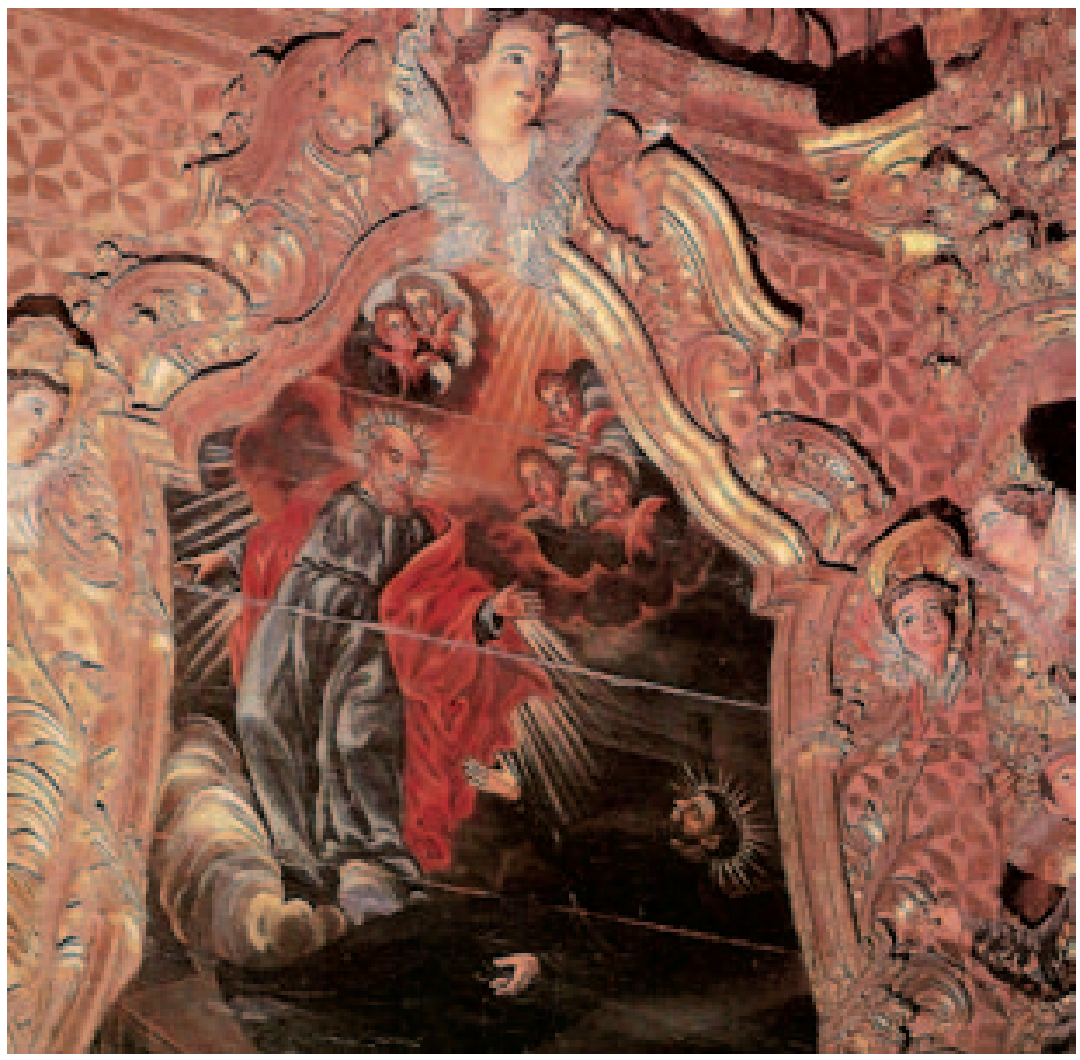

\section{Figura 3}

[Francisco Coelho?]. Morte de São Francisco Xavier. c. 1745-1755.

Óleo sobre madeira, Catedral Basílica de Salvador.

49 Os dizeres atribuídos tradicionalmente a Jesus para aquela ocasião são os que remetem ao sentimento de abandono em meio à agonia vivida "Deus meu, Deus meu, por que me desamparaste? Por que te alongas do meu auxílio e das palavras do meu bramido?" (SI 22, 1), mas a continuidade da passagem citada revela sua confiança de que Ele viria ao seu encontro: "Porque não desprezou nem abominou a aflição do aflito, nem escondeu dele o seu rosto; antes, quando ele clamou, o ouviu" (Salmos 22, 24). Nesse sentido, vemos em Xavier o conforto tão desejado sendo consumado. 
Isso poderia remeter também a uma visão de Xavier, tal qual representada por Luca Giordano e Paolo de Matteis em séries da vida do santo de finais do século XVII. Giordano e Matteis, mestre e discípulo que executaram obras juntos, pintaram a visão das cruzes ou dos trabalhos de Xavier na qual o santo teria sonhado com seus trabalhos no Oriente, porém inseriram na imagem a figura de Deus Pai e sua corte celestial. A composição apareceu na Il Gesù Nuovo dos jesuítas em Nápoles, sob o pincel de Giordano, entre 1690 e 1692, e na Igreja de São Ferdinando em Nápoles e na Catedral de Córdoba, executados por Matteis entre 1692 e 1695, originalmente parte de uma série para o Colégio Imperial de Madri, continuando obra comissionada a Giordano. ${ }^{50}$ Há uma semelhança entre a posição de Deus Pai na visão das cruzes ou dos trabalhos de Giordano mas sobretudo de Matteis e a do painel de Salvador. ${ }^{51}$ Essa proximidade visual faz pensar sobre a sobreposição de episódios no painel na igreja do colégio baiano. Se unidos visualmente, juntariam a morte no Oriente após a missão, com o anúncio dos trabalhos missionário no mesmo Oriente. Morte gloriosa, após tribulações e sacrifícios mas também milagres e conversões, como a vida de Jesus, e visão profética desses trabalhos futuros que teriam como fim um martírio que, exemplarmente, remetia a morte de Cristo. Tendo sido intencional ou não, esta sobreposição aqui levantada permite voltar a outro painel do altar de Xavier e entrar no tema dos sonhos e das visões.

\section{Sonho}

Entre os retratos de milagres do altar de Salvador, há uma imagem que remete mais diretamente a uma das visões do santo, elemento importante junto à morte (e aos milagres) em sua hagiografia visual. A visão escolhida era uma bastante recorrente e era retirada das primeiras narrativas da vida de Xavier. Era um sonho que tivera em Roma no qual se via carregando um homem gigantesco e, ao acordar, estava com o corpo dolorido e cansado como se tivesse mesmo suportado o peso daquele imenso gentio. Difundido, a partir do relato do padre Diego Lainez pelo qual o santo dissera-Ihe sentir moído por ter, em sonhos, levado um índio muito pesado às costas que não conseguia quase levantar, o sonho ganhou melhor forma e papel central no restante da hagiografia na escrita de Lucena (como de outros biógrafos que o seguiram). Contudo, Lucena adicionou elementos, qualificando o dito índio sonhado como que parecendo um etíope, isto é, africano: "Índio

50 GUTIÉRREZ PASTOR, Ismael. La serie de la Vida de San Francisco Javier del Colegio Imperial de Madrid (1692) y otras pinturas de Paolo de Matteis en España. Anuario del Departamento de Historia y Teoría del Arte, n.16, p.99100, 2004; TORRES OLLETA, Maria Gabriela. Redes iconográficas, p.212-213, fig. 165, 171, 172.

51 Não sabemos ao certo os modelos de Giordano e Matteis para a sua imagem como desconhecemos gravuras feitas a partir de seus óleos, que pudessem ter chegado aos irmãos pintores em Salvador. 
negro, como os da Etiopia". ${ }^{52} \mathrm{Na}$ explicação de Lucena, a interpretação do sonho dizia ser aquela imagem a revelação de sua luta pela conversão dos gentios, no qual o Índio seria a própria figura das Índias, como se chamavam as possessões asiáticas dos portugueses, e palco no qual Xavier atuaria. Para Ines Zupanov, contudo, esse atributo (etíope) dado por Lucena e outros biógrafos portugueses poderia implicar uma tentativa de também incluir na visão a África, onde a missão jesuítica e o domínio português, na virada do século XVI para o XVII, passava por reveses. ${ }^{53}$ Se esse movimento fizer sentido, a descrição do sonho somada a sua interpretação faziam com que o sonho de Xavier abarcasse África, Ásia e América, todos os três a serem subjugados pelo Império Português e convertidos pelos jesuítas para maior glória de Deus ${ }^{54} \mathrm{~A}$ partir dela, o sonho foi divulgado e foi vertido da letra para as tintas, porém muitas vezes permanecendo com essa dubiedade de como era o tal índio.

Devemos voltar um pouco, entretanto, e lembrar que o sonho do índio não apareceu nas séries de Regnartius nem de Reinoso, ainda que, em ambas, haja menção indireta a outro sonho, o dos trabalhos, também presente em Lucena. Xavier estava em Roma, trabalhando em um hospital "em seruiço dos enfermos", quando em uma noite seu colega de câmara, padre Simão, acordou com ele gritando enquanto dormia, "Mais, Mais, Mais". ${ }^{5}$ Xavier só revelou o sentido da visão quando se despedia de Simão em Lisboa, ao embarcar para o Oriente:

Eu vi ali, ou em sonhos, ou velãdo (Deos o sabe) grãdissimos trabalhos, fadigas, \& apertos de fomes, sedes, frios, caminhos, naufragios, treições, perseguições, \& perigos, que se me offereciam polo divino serviço, \& amor. E o mesmo Senhor me dava entam graça pera me fartar delles, \& e lhe pedir mais, \& muytos mais, com aquellas palavras, que ouvistes. E assi espero em sua divina bondade, que me comprirá liberalmente nesta jornada os offerecimentos, que ali me fez, \& os desejos, que ali me deu. ${ }^{56}$

O capítulo no qual é narrado o sonho dos trabalhos, e também o do índio, trata de "Como Deos o [Xavier] escolheo pera a missam na India", indicando a importância da visão (seja sonho ou visão noturna, como dizia Xavier) na trajetória santa do missionário e que seu percurso se fundava em sofrimento, peregrinação, perigo.

52 LUCENA, João. Historia da Vida do Padre Francisco Xavier, p.27.

53 ZUPANOV, Ines. Missionary Tropics, Jesuit Frontier in India (16th-17th century). Ann Arbor: University of Michigan Press, 2005, p.35-42.

54 Cf. VIEIRA, Antônio. Sermoens do P. Antonio Vieira da Companhia do lesu, Prégador de Sua Alteza. Segunda parte dedicada no panegyrico da Rainha Santa ao Serrenissimo nome da Princeza N. S. D. Isabel. Lisboa: Officina de Miguel Deslandes, 1682, p.137.

55 LUCENA, João. Historia da Vida do Padre Francisco Xavier, p.27.

56 LUCENA, João. Historia da Vida do Padre Francisco Xavier, p.40-41. 


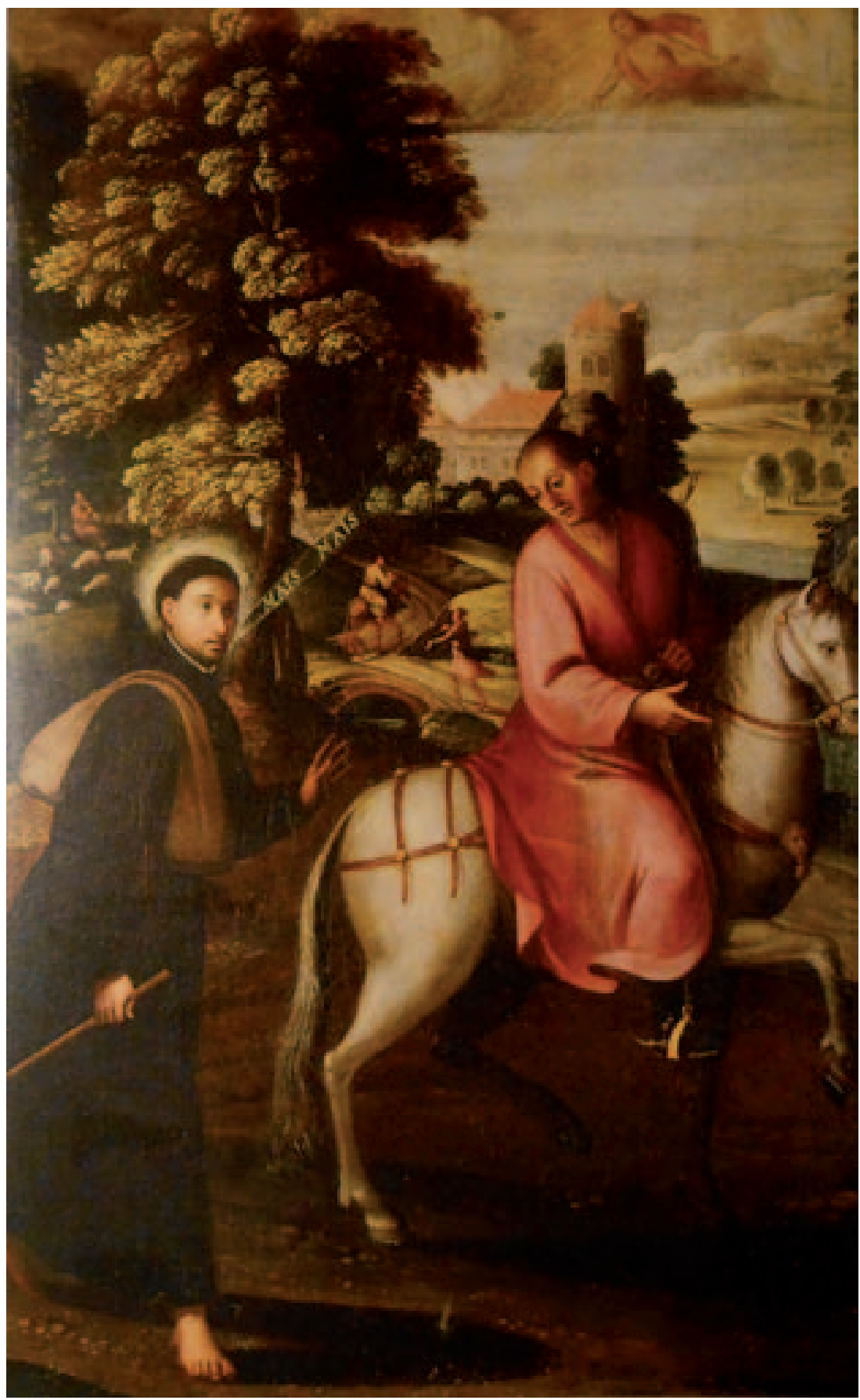

\section{Figura 4}

Oficina de André Reinoso. Viagem até Meaco. c. 1619.

Óleo sobre tela, Sacristia da Ig. de S. Roque, Lisboa. 
Na série da sacristia de São Roque, em Lisboa, há, entre as 20 telas, uma na qual Xavier era retratado andando atrás de um cavalo no qual estava montado um homem de vestes e feições orientais (Figura 4). Xavier, com uma auréola de luz, na parte inferior esquerda, aparecia com a mão em posição de bênção olhando para o cavaleiro que se virava para ele, enquanto no canto diametralmente oposto aparecia entre as nuvens a figura de Deus que, cercado de luzes, se inclinava em direção à Xavier. Essa disposição formava como que um triângulo, no qual a iluminação divina chegava à Xavier, santificado por uma auréola, diretamente de Deus criador e que a transmitia, humildemente de pés descalços, para o soberbo Oriental em cima de seu cavalo e que estava verticalmente abaixo da imagem divina. Para além da metáfora do trabalho catequético como intermediário da presença divina no mundo, havia um elemento que interessa aqui e que reforça a dimensão profética: da boca de Xavier saiam os dizeres "Mais, Mais". Aquela imagem era uma representação pictórica dos sonhos narrados por Lucena e lembravam pelo exemplo de seu irmão célebre o pregador de qual a sua missão e qual o objetivo de sua Ordem. A visão dormindo dos trabalhos futuros de Xavier consubstanciava-se numa iconografia da humildade que revelava, entretanto e por isso mesmo, a participação na Glória e Graça divinas.

O interessante dessa imagem em São Roque é que condensaria dois episódios, se a compararmos ao programa iconográfico estabelecido no ciclo de Regnartius: o dos trabalhos, presente na terceira gravura da série (numa imagem na qual Xavier segura a cruz rodeado por anjos, e a legenda informando que ele pedia mais), e o do percurso até Meaco, atual Quioto, que realiza na condição de lacaio de um nobre japonês, retratado na sétima gravura (na qual, à direita, anda descalço atrás de um homem de costas, com chapéu, montado num cavalo, à esquerda). A sétima gravura de Regnartius, mais até do que a terceira, tornou-se composição recorrente em diferentes séries. Aparece em alto-relevo no túmulo em Goa, de 16361637, construído a partir dos planos e desenhos do jesuíta italiano Marcelo Mastrilli; num livro de devoção, Cultus Sancti Francisci Xaverii, impresso após a morte de Mastrilli, em Viena, repleto de gravuras, que se seguiam a modo de emblema, cada uma apresentada sob um mote que indicava a virtude do santo com uma legenda explicando a cena, sendo que nesta se elogiava a paciência de Xavier; num ciclo de gravuras dos Países Baixos, da segunda metade do século XVII, reimpressa por diferentes gravadores; em azulejos no Hospital de Arroios, no século XVIII em Lisboa; no ciclo de 30 painéis a óleo do convento de La Merced, em Quito, pintados em meados do século XVIII. ${ }^{57}$

57 MORMANDO, Franco; THOMAS, Jill G. (ed.). Francis Xavier and the Jesuit Missions in the Far East. An Anniversary Exhibition of Early Printed Works From the Jesuitana Collection of the John J. Burns Library, Boston College. Chestnut 
De qualquer modo, o sonho não é evidenciado em nenhum desses dois ciclos iniciais. Sequer o é, na verdade, pelo próprio relato de Xavier, que fica em dúvida, nas palavras de Lucena, se vira em "sonhos, ou velãdo". Podemos aqui pensar inicialmente que essa elipse da visão onírica (ainda que central na narrativa, pois sinal da eleição do santo para seu trabalho missionário no Oriente) ${ }^{58}$ tivesse a ver com o estatuto ambíguo que o sonho possuía. ${ }^{59}$ Ainda que canal de comunicação com o divino presente na Bíblia e reconhecido por Agostinho, Aquino e outros, o sonho era também uma das formas de visão mais simples e menos confiáveis. Como pertencia às visões imaginativas, mediada por imagens, e não às diretamente intelectivas, por pura inspiração, como as visões consideradas superiores, o sonho profético dependia das semelhanças e analogias das coisas corpóreas, o que implicava um véu entre o vidente e a revelação. Além disso, era muito suscetível aos delírios aleatórios das imagens soltas do discernimento durante o sono. Na classificação de Aquino, desenvolvida a partir da hierarquia de Agostinho, a visão onírica era o degrau mais baixo das visões proféticas propriamente ditas, logo acima das inspirações divinas que movem os instintos. Como explicado na Suma teológica, ${ }^{60}$ a visão tida durante o sono era inferior pois os sentidos dormentes não permitiam nem uma compreensão completa nem um discernimento real. O sono, por sua vez, como metáfora da morte, não primava com a ideia de vigilância e disposição requeridas a uma vida cristã.

Paralelamente, foi durante o século XVII que o sonho ganhou espaço como figura eficiente de explicação seja dos limites do conhecimento humano (Descartes) seja da transitoriedade da vida terrena e de seu caminho para a morte (Calderón, Shakespeare). O sonho era um lembrete constante de que as coisas vividas eram figurais, pois mero sinal da verdade sobrenatural, que seria enfrentada (eternamente) após a morte. A metáfora da vida como sonho, expressa no título de uma peça de Calderón, emblematizava uma cultura na qual a teatralidade e a farsa eram entendidas como figuras da transitoriedade e fugacidade do mundo terreno. Exatamente por seu estatuto contrário à vigília e pelo primado da imaginação, o sonho, na gramática tridentina e católica, ganhava força, em termos figurais, imagéticos e retóricos, como exemplo máximo do que era importante na vida (o verdadeiro despertar), e aviso moral do que deveria se evitar (as delícias mundanas). Ao mesmo tempo, se houvesse uma profecia, a visão dormindo ganhava estatuto divino (e de verdade, portanto), sem perder seu efeito

Hill: The Jesuit Institute of Boston College, 2006, p.37; TORRES OLLETA, Maria Gabriela. Redes iconográficas, p.560, p.729. Cf. RODRíGUEZ G. DE CEBALLOS, Alfonso. Las pinturas de la vida de San Francisco Javier del Convento de la Merced de Quito: fuentes gráficas y literarias. Anales del Museo de América, n.15, p.89-101, 2007. 58 Para uma análise da importância dessas visões e sonhos na construção da hagiografia de Xavier e mesmo como elemento para pensar sua biografia, ver a análise de Ines Zupanov (Missionary Tropics, Jesuit Frontier in India).

59 JORDAN ARROYO, Maria. Da imaginação à imagem, p.161-164.

60 AQUINO, Tomás de. Suma Teológica, II-II, q.174, a.3. 
verossímil de mover e deleitar as audiências com os jogos engenhosos entre vigília, sono, sonho, despertar, e ensiná-las sobre o que importava de fato na existência humana - perseguir a transcendência divina. A indistinção e a conversibilidade entre uma visão em sonho ou acordada eram recorrentes nas hagiografias e na produção letrada seiscentistas, ora para dar maior certeza ao estatuto profético da visão, ora como dispositivo retórico-poético da transitoriedade da vida desperta. Se por um lado havia a busca em definir e separar os tipos de visão e em distinguir a verdadeira da falsa profecia, o embaralhamento e a indistinção entre sonho e visão eram eficazmente empregadas como figura da relação entre vida e morte mediada pela presença divina. ${ }^{61}$

Não nos parece descabido, nesse sentido, que cada vez mais os sonhos aparecessem nos ciclos e nas representações imagéticas do santo, reforçando, por vezes e agora positivamente, a indistinção entre visão acordada e dormindo descrita por Lucena. De inexistentes nos dois primeiros ciclos mais importantes, começam a ser presentes, enfatizando a visualização das cenas sonhadas, por meio dos índices das visões oníricas (o índio e os símbolos dos trabalhos). Nessa direção, vale notar que um outro sonho de Xavier pouco foi representado: aquele no qual demônios o tentam com uma imagem impura que machucam sua castidade, sua reação de repúdio é tão violenta que "aos primeiros acenos della a rebateo com tanta violencia de espirito, que lhe saltou das veas o sangue puro". ${ }^{62}$ Apesar do tema das tentações demoníacas (e sua resistência) ser recorrente nas hagiografias jesuíticas e ter certa veiculação imagética, por meio de gravuras, em especial a partir da série imagética da vida de Inácio, impressa em 1609 e desenhada por Rubens, ${ }^{63}$ uma das poucas imagens que localizamos da visão pecaminosa foi no livro Cultus Sancti Francisci Xaverii, ${ }^{64}$ que ao modo do Vita de Inácio, contava a vida de Xavier por imagens, mas com o objetivo mais explícito de dar elementos virtuosos para sua veneração.

Diferentemente de Inácio que é atacado com punhos e paus pelos demônios musculosos enquanto permanece inerte na cama de sua cela, na gravura vienense, Xavier é retratado deitado no chão, ao pé do altar, fazendo um sinal com as mãos para afastar o diabo alado de feições femininas e seu companheiro de tentações sexuais, Eros, enquanto olha para o outro lado cuspindo sangue e com a cabeça em direção a um livro, que supomos ser a Bíblia. Enaltecem-se sua reação física a uma visão

61 LIMA, Luís Filipe Silvério. Império dos sonhos: profecias oníricas, sebastianismo e messianismo brigantino. São Paulo: Alameda, 2010, esp. cap.1, 2, 7; LIMA, Luís Filipe Silvério. Vida e sonho em Calderón de La Barca. In: PIRES, Francisco Murari. Antigos e modernos. São Paulo: Alameda, 2009, p.357-370.

62 VIEIRA, Antônio. Xavier dormindo, e Xavier accordado. 1694, p.106.

63 RUBENS, Petrus Paulus. Vita Beati P. Ignatii Loiolae Societatis lesv Fvndatoris. Roma: (s.n.), 1622 (1609), grav.67.

64 Cultus Sancti Francisci Xaverii Soc. Jesu. Japoniæ, \& Indiarum Apostoli. Viennæ: Gregorii Kurtzböck, s.d., s.p., In: MORMANDO, Franco; THOMAS, Jill G. (ed.). Francis Xavier and the Jesuit Missions in the Far East, p.38. 
imaginária, causada por influxo maligno e exterior. ${ }^{65}$ Do mesmo modo, na visão dos trabalhos, ressalta-se seu grito, que foge ao campo do sonho pois ecoara no quarto despertando Lainez, e por fim, no sonho do índio, acorda com o corpo moído e magoado, efeito de ter carregado e lutado dormindo. Nos três sonhos - (1) em que aparecia lutando e carregando às costas um índio gigantesco (2) conhecendo as desgraças que sofreria em sua missão, mas mesmo assim pedindo "mais, mais, mais" e (3) sendo tentado pelo demônio com imagens pouco castas - a dimensão física, corporal era presente, não só confirmando o efeito dos sonhos e sua verdade, pois presente no mundo da vigília, dos despertos, mas também indicando o poder da imaginação e das imagens e o cuidado que se deveria ter - percepção e alerta presentes nos próprios Exercícios espirituais de Loiola. Aqui talvez encontremos uma hipótese para a preferência de representar visualmente o sonho do índio: mais do que os outros dois, a cena de Xavier carregando alguém nas costas traduzia melhor a relação entre imagem e corpo, e a necessidade de controlar ambos, fosse dormindo, fosse acordado. Entretanto, as formas de construir plasticamente essa visão foram as mais variadas, sem um padrão iconográfico recorrente, e, mais importante para o presente artigo, foram ficando mais comuns nas séries pictóricas ao longo dos séculos XVII e XVIII.

A primeira representação do sonho do índio que identificamos está num dos panfletos compostos para a divulgação dos feitos do jesuíta no Oriente, tanto como divulgação dos feitos exemplares para os jesuítas quanto antes ainda como esforço para sua beatificação. Nessa gravura de 1605, o retrato de Xavier ocupa o centro, com as mãos ao peito, iluminado pelos céus, sendo o retrato cercado por 14 quadrinhos representando cenas de sua vida, entre elas, o sonho. ${ }^{66} \mathrm{O}$ episódio está, contudo, entre as quatro menores representações, colocada entre duas imagens maiores. Reapareceu somente em 1622, produzida em meio às festas de sua canonização, pela mesma ocasião da série de Regnartius. Figurava em local nobre, no óleo produzido, por Anthony Van Dyck para ser disposto na Igreja dos jesuítas em Roma, II Gesù. Nesse óleo, como no folheto de 1605, a cena apresenta-se mais uma vez enquanto um detalhe, no canto inferior esquerdo de uma tela tomada também em sua maior parte por um retrato de Xavier, com as mãos ao peito, com raios vindos dos céus em sua direção, agora coroado por anjos por uma grinalda de louros e flores. No detalhe do sonho, visível em certa medida pela grande dimensão do quadro $(3,46 \times 2,14 \mathrm{~m})$, entretanto, o índio negro, etíope virara uma figura de um velho barbudo vestido à indiana, semelhante a um brâmane, sus-

65 Castidade de Xavier. Após 1634. Gravura, Viena, In: Cultus Sancti Francisci Xaverii Soc. Jesu. Japoniæ, \& Indiarum Apostoli.

66 TORRES OLLETA, Maria Gabriela. Redes iconográficas, fig.36, p.518. 
tentada por Xavier. Na leitura de Van Dyck, que deve ter sido informada e direcionada pelos jesuítas romanos, dada a importância não só do santo mas da igreja e do altar que ocupava em meio às festas em sua celebração, a classificação "índio" servia para qualquer uma das Índias, e mais do que isso, na sua tradução visual remetia ao Oriente, palco de atuação do então santificado "Apóstolo do Oriente". O óleo depois, em 1679, foi substituído no altar da II Gesù pela imagem da morte de Xavier, pintada por Maratti. A mudança da cena do altar pode indicar duas coisas: o reforço da ideia do martírio e sua analogia com a imagem de Cristo (mais fortes do que a remissão ao sonho) bem como a inserção da presença americana na iconografia xavieriana, ao trocar a figura de um brâmane ou de um indiano por, entre outros, um homem com cocar de plumas a remeter ao mundo americano.

A partir de meados do século XVII, o "índio" asiático foi traduzido, muitas vezes, numa figura ameríndia, de pela avermelhada, portando cocar, por vezes, vestindo saiote de plumas. Aparece já dessa forma na gravura "Somnium Xauerii de subsidio Indis ferendo" do Imago primi saeculi Societatis lesu (1640), impresso da Companhia, da província de Flandres por conta do centenário de fundação. Mais uma vez um volume que trazia imagem e texto em conjunto remetendo a uma composição emblemática, forma que se casava com uma concepção retórico-teológica de analogia entre palavra e figura. Baseava-se essa concepção num entendimento da imaginação como caminho (possível) para o entendimento e o discernimento, mas também para a tentação e a perdição, razão pela qual deveria ser regulada e controlada em todas as suas formas, escritas, orais ou visuais. Nesse volume, editado na prestigiosa casa Plantin-Moretus, as gravuras apresentavam além da alma (o mote) e o corpo (a imagem), o epigrama, os versos que amplificavam o mote e se espelhavam na imagem, muitas vezes apresentada em enigma ou de modo figural ou alegórico. Na gravura em questão, os versos abaixo perguntavam se devíamos acreditar nos sonhos, para em seguida dizer que aqueles sonhos de fé eram, em parte porque resultavam do amor de Xavier pelo outro a ser convertido e pela sua missão - matéria do sonho, pois aquilo que amamos nos vêm à noite. Agora, contrário à própria imagem, referia-se ao índio não só como negro (como em Lucena) mas como mouro, adicionando outro espaço e povo à ação missionária do jesuíta. ${ }^{67}$

67 BOLLAND, Johannes et. al.. Imago primi saeculi Societatis lesu: a prouincia Flandro-Belgica eiusdem Societatis repraesentata. Antuérpia: Ex officina Plantiniana Balthasaris Moreti, 1640, p.720. 


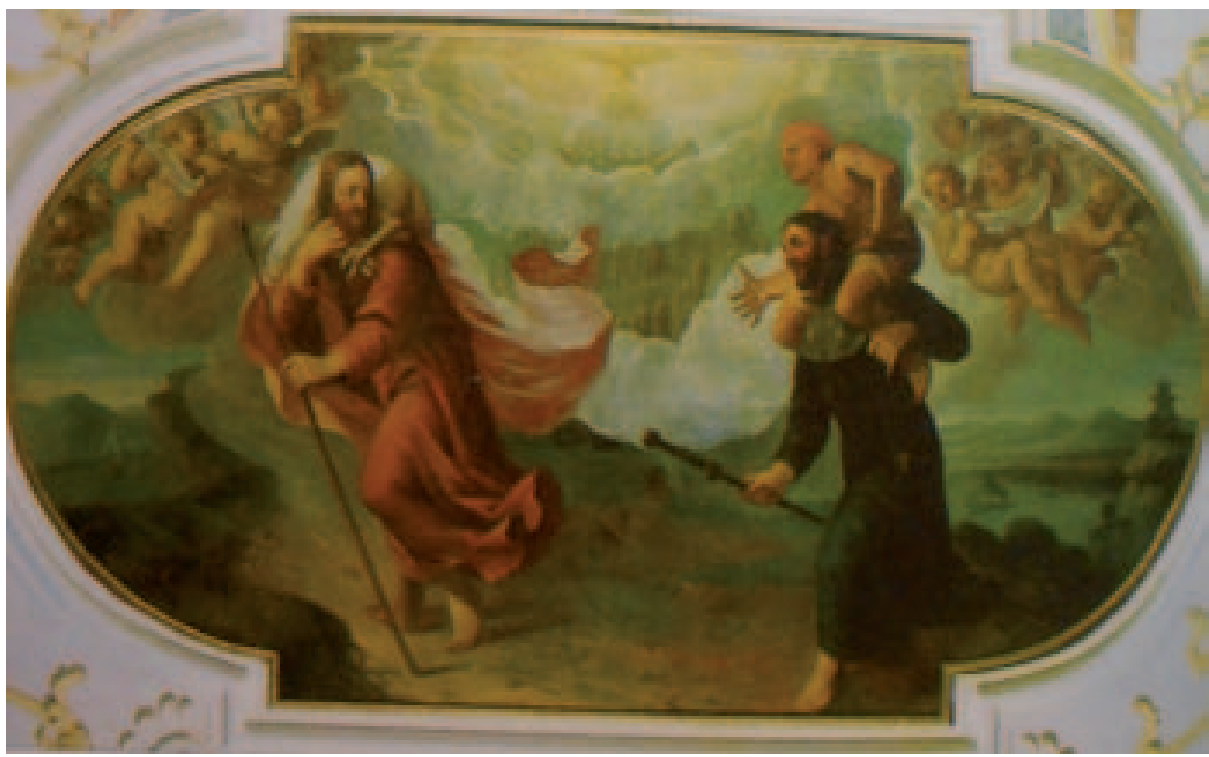

Figura 5

POTMA, Jakob. São Francisco Xavier como bom pastor, 1694, Afresco, Igreja Jesuíta de Mindelheim, Bavária.

O índio também foi retratado com signos americanos em 1694 pelo pintor polonês Jakob Potma no afresco da igreja jesuítica de Mindelheim (Figura 5), na Bavária, região de forte devoção ao santo jesuíta. No afresco, Xavier leva nos ombros um ameríndio de cocar vermelho e de peito desnudo, e olha para frente, pois segue Cristo que carrega às costas uma ovelha e porta um cajado de pastor, lançando um olhar para trás em direção ao missionário jesuíta. Cercando ambos uma corte de querubins e, entre eles, acima, nos céus, e na metade da pintura, a pomba do Espírito Santo. A analogia entre a figura de Jesus como bom pastor e de Xavier como missionário é bastante clara visualmente, reforçando o duplo exemplo do santo, imagem de Cristo, e imagem a ser seguida. Isso era particularmente forte, em região e época, Sul da Alemanha do século XVII, que a figura de Xavier era utilizada pela Companhia em seus esforços de propagação da fé, elevando-se altares e mesmo igrejas em sua devoção, e que muitos noviços postulavam o trabalho nas missões (e desejavam o martírio) inspirados no sacrifício do jesuíta. ${ }^{68}$ Segundo Christoph Nebgen, as cartas indipetae, com os pedidos dos jovens para o geral da Ordem, postulavam seguir a vida do santo na Ásia e, assim, de modo duplamente figural, também imitar o exemplo pastoral e de sacrifício

68 NEBGEN, Christoph. S. Francisco Xavier: "Luz del Oriente" como santo patrono del Occidente. In: SANTOS, Zulmira (org.). São Francisco Xavier nos 500 anos do nascimento de São Francisco Xavier. 
do próprio Salvador. Não pediam pela América - ainda que a trajetória de irmãos germânicos no Brasil fosse noticiada nas cartas edificantes - à qual remetia iconograficamente o índio suportado por Xavier. De certa maneira, o esforço do programa visual (que ecoava e completava um programa de festas, textos, sermões...) nos reinos alemães católicos era para transformar Xavier de santo do Oriente em "primer 'Santo Mundial'", 69 e como parte desse esforço pode ser entendido o ameríndio de Potma - ou mesmo, ainda na cena da morte, a figura emplumada na cena de pregação de Xavier, no Altar-mor da Igreja de São Francisco Xavier, em Paderborn (1694/1696), bem mais ao norte da igreja bávara. Já na América em meados do século $\mathrm{XVIII}$, é com essas características que foi pintado o índio do ciclo de Quito, no convento de La Merced. A composição, porém, mistura, do lado direito da tela, o interior da cela, onde Xavier sonhou e na qual aparece de pé com o índio agarrado às suas costas tendo um querubim acima mostrando as cruzes dos seus trabalhos (plasmando aqui outro sonho, que aparece, por sua vez, na tela anterior do ciclo), e, do lado esquerdo, o cenário de seus trabalhos: curiosamente, uma terra cercada por mar, na qual estavam ajoeIhados ameríndios semi-nus emplumados venerando um anjo que apontava, por sua vez, para um navio que se aproximava da Costa. ${ }^{70}$

Também por volta de 1750, a representação que está na atual Catedral Basílica de Salvador ganhou outros contornos (Figura 6). Menos do que um gigantesco índio, ou um homem em vestes brâmanes, Xavier carrega uma figura quase púbere, negra, de carapinha, e vestido com um trajo listrado. De índio etíope, de indiano, de ameríndio, aparece-nos no painel de Salvador um garoto negro. Retorno ao "negro como etíope" de Lucena? Pode ser, já que por etíopes eram chamados os africanos escravizados no Brasil. Contudo, aqui o personagem etíope não se vestia como um índio, com cocar e penas, como em imagens dos séculos XVII e XVIII nas quais se fez plasmar os elementos "índios" com os do negro "etíope", como nas gravuras de Imago Printi, 1640, da Vita S. Francisci Xavierii Soc. lesu, de 1690, na América no óleo de Antônio de Torres, de 1720, na Casa Professa da cidade do México, ou, já em fins do século XVIII, na gravura do italiano Stefano Piale no livro do jesuíta Filippo Salvatori sobre os "Fatti più rimarchevoli" da vida do santo. ${ }^{71}$ No óleo mexicano, há uma remissão à composição presente na Vita de 1690,

69 NEBGEN, Christoph. S. Francisco Xavier: "Luz del Oriente" como santo patrono del Occidente, p.115-116.

70 TORRES OLLETA, Maria Gabriela. Redes iconográficas, p.679, fig.230; Cf. RODRíGUEZ G. DE CEBALLOS, Alfonso. Las pinturas de la vida de San Francisco Javier del Convento de la Merced de Quito. A legenda, que está na moldura, explica a composição em duas cenas: "Es elegido Xavier para apostol de la Yndia por medio de un sueño en q le parecia cargar sobre sus ombros a un yndio y al mismo tiempo se le reprecentaban los trabajos en el Oriente para donde salio de Lisboa en 7 de abril de (sic)1641".

71 TORRES OLLETA, Maria Gabriela. Redes iconográficas, p.758, fig.336, p.659, fig.208; Antônio de Torres (16661731), "São Francisco Xavier carregando um índio", 1720, óleo sobre tela, Pinacoteca, Templo de San Felipe Neri, Casa Professa, Cidade do México, México; MORMANDO, Franco; THOMAS, Jill G. (ed.). Francis Xavier and the Jesuit Missions in the Far East, p.89. 
que deve ter possivelmente servido de modelo para Torres. ${ }^{72}$ Lá estão não só o africano com cocar e saiote de plumas, ainda que com uma sombrinha senhorial, mas também, ao fundo, separados num segundo plano por um rio da cena principal do sonho do santo, índios armados com arcos e flechas em torno das cabanas de sua aldeia. Novidade em relação às gravuras, aparece um anjo que olha para o jesuíta, com ele parece se comunicar e apontar, com sua mão direita, o caminho - oráculo que, aparecendo em sonho, reforçaria o caráter divino da mensagem vista dormindo. Na gravura italiana de 1793 (com a ordem já extinta), o índio negro, menos do que em posição hierática, parece de fato esmagar o jesuíta que mal consegue levantá-lo, dobrado que está perante o peso do "gigantesco indiano". Xavier, entretanto, ainda tem forças para tentar olhar para o alto e ver o anjo que carrega a multidão de cruzes, representando o outro sonho, o dos trabalhos, sobrepondo as duas visões como no óleo de Quito (e mesmo no livro de Lucena).

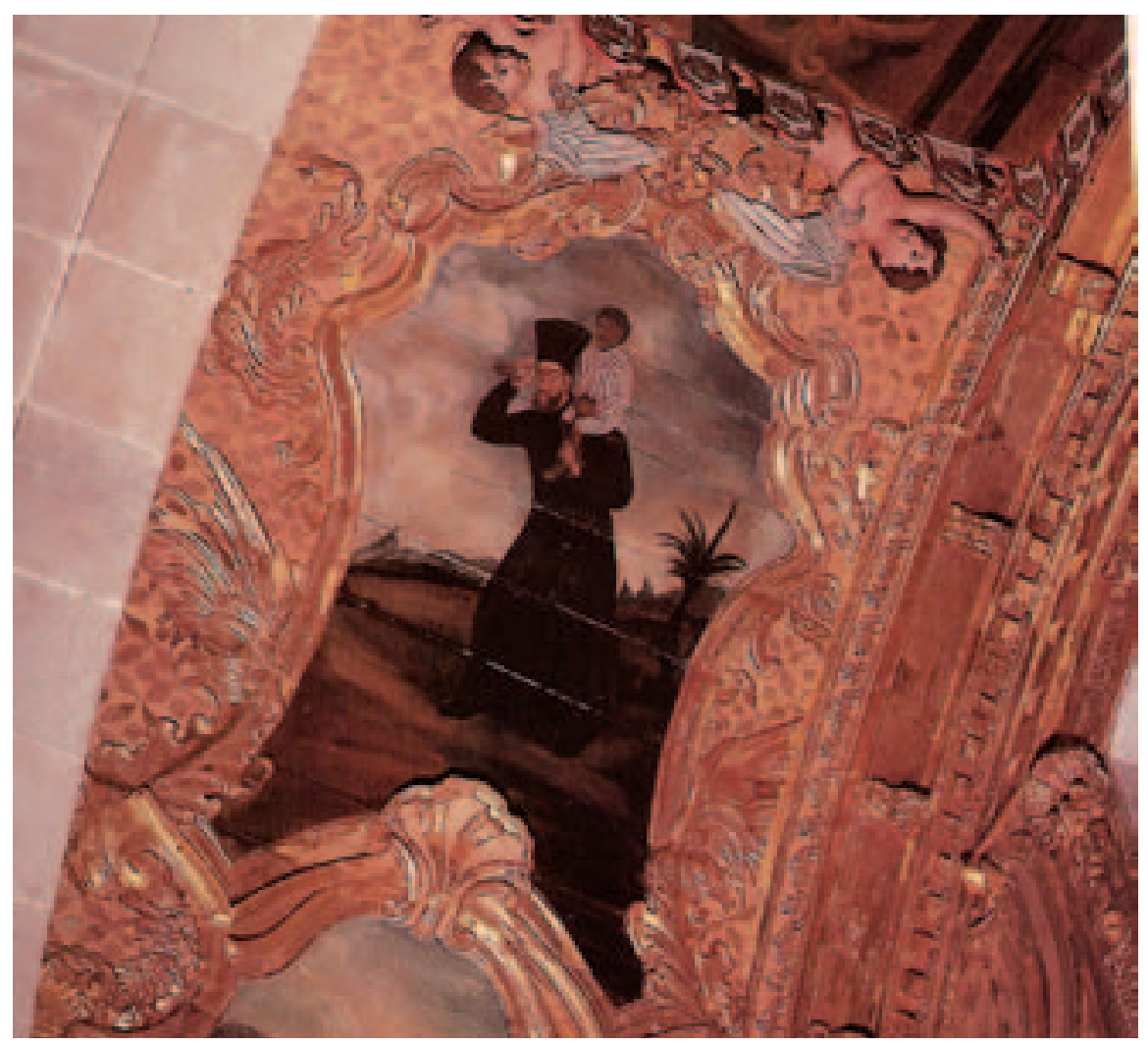

Figura 6

[Francisco Coelho?]. Sonho do índio. c. 1745-1755.

Óleo sobre madeira, Catedral Basílica de Salvador.

72 Ver a base de dados on-line do PESSCA. 
No painel baiano, entretanto, o "indiano" vinha trajado de modo similar às de representações dos escravos que circulavam à época, e se mostrava diminuto em relação ao jesuíta. Aqui, o menino pequeno sobre o ombro do santo talvez remeta à iconografia de São Cristovão. A sua legenda dizia que o santo carregou uma criança de uma margem à outra de um rio caudaloso, a criança ficava a cada passo mais e mais pesada, e o homem com aquele peso às costas preocupou-se pois poderia se afundar nas águas perigosas. Ao cruzar o rio, interpelou o menino sobre aquele peso que os colocara em perigo, e este revelou ser Cristo, e o peso que sentira era porque carregara não somente "o mundo sobre si, como carregou em seus ombros aquele que criou o mundo". ${ }^{73} \mathrm{O}$ paralelo entre os episódios hagiográficos do sonho de Xavier e da travessia de Cristóvão é aqui forte (e o rio no óleo de Torres e na gravura da Vita de 1690 talvez sejam índice disso), talvez reforçando de outra maneira a analogia entre a visão onírica do santo jesuíta e a presença de Jesus. Entretanto a composição remete a outra representação visual do próprio episódio, em Goa. Na urna funerária de Xavier, na Igreja de Bom Jesus de Goa, entre as 32 cenas de sua vida em alto-relevo em prata, apresenta-se também o sonho do índio. Produzida entre 1636-1637, Xavier, com uma auréola, está ajoelhado, segurando sobre o ombro esquerdo um menino, seminu, coberto por panos, rezando. A composição, grosso modo, repete-se na capela dedicada ao santo, em um painel, no qual o garoto tem a tez mais escura que o santo. ${ }^{74} \mathrm{~A}$ semeIhança com a imagem de São Cristóvão é novamente evidente, mas vale a pena observar que, em ambos os casos, a representação do menino lembra figuras devocionais de Buda, com a barriga, algo proeminente, a mostra, o cabelo curto, quase raspado (sobretudo no óleo), o que pode fazer pensar nas circularidades culturais e nas influências de repertórios visuais locais na confecção desses artefatos devocionais cristãos. ${ }^{75}$ Visto que até onde pudemos verificar esses são os três únicos exemplos dessa composição, talvez o irmão Francisco Coelho, suposto autor das pinturas do colégio da Bahia, tivesse tido algum contato, mesmo que indireto, com essas imagens de Goa. Isso não seria algo inaudito na circulação cultural no Império Português nem na dinâmica da Companhia.

Não somente na representação do "índio etíope" há peculiaridades no painel baiano; a figura de Xavier também foi retratada de maneira diversa

73 VARAZZE, Jacopo. Legenda Áurea. São Paulo: Companhia das Letras, 2003, p.573. Por conta disso, a pintura fo erroneamente identificada como representando São Cristovão levando Cristo: VALLADARES, Clarival do Prado. Nordeste histórico e monumental. v.IV, Salvador: Odebrecht, 1991, p.192-3.

74 TORRES OLLETA, Maria Gabriela. Redes iconográficas, fig. 275-276; para uma descrição dessas séries, ver p.258-267.

75 Sobre Buda na imaginária cristã produzida no Oriente, ver: BAUMGARTEN, Jens. Anacronismo e alteridade na arte colonial. In: COUTO, Maria de Fátima Morethy; CAVALCANTI, Ana Maria Tavares; MALTA, Marize (org.). Anais do XXXI Colóquio do Comitê Brasileiro de História da Arte. Campinas: Comitê Brasileiro de História da Arte, 2011, p.91-109. 
do usual. Por alguns detalhes, as vestes e o cabelo que caracterizavam o jesuíta apresentam-se de outro modo. Se a barba permanece, se mostra hirsuta, mais longa do que costumeiro; a tonsura, se existente, está escondida sob um chapéu volumoso e alto, que não era usual na iconografia xavieriana, pois mesmo quando aparecia com chapéu era um barrete mais baixo. ${ }^{76} \mathrm{~A}$ figura lembra um outro jesuíta que esteve na China, Matteo Ricci (1552-1610), que conhecia a língua chinesa, ao contrário de Xavier, que nunca aprendera nenhuma língua asiática. Pelo seu conhecimento e pelo seu esforço de traduzir o cristianismo para o chinês, Ricci era representado em vestes orientalizantes, que adotara de fato nesse esforço de ser aceito para converter de dentro a China. Nas gravuras que o retratam, os trajes à maneira asiática eram completados por um chapéu, muito similar ao usado pelo Xavier da igreja de Salvador. Ambos, inclusive, já em inícios do século XVII, haviam sido postos lado a lado no frontispício da edição do relato da missão jesuítica na China de Matteo Ricci, impressa em Augsburg em 1615. A gravura da portada, feita pelo impressor Wolfgang Kilian, foi reproduzida em diferentes edições. Nela aparecem, ladeando o título e o mapa da China, Xavier à esquerda, com vestes de pregador, e Ricci à direita, trajado à chinesa, um de frente para o outro. ${ }^{77}$

Se, por um lado, a tez escura nos remete ao relato como narrado por Lucena, por outro, sua roupa lembra-nos dos escravos etíopes no Estado do Brasil, cuja capital (cabeça) era Salvador, ao mesmo tempo que o seu tamanho e o modo como é carregado assemelha-se à mesma cena retratada em Goa (além da homologia com São Cristovão carregando Cristo). Se as vestes negras e a barba permanecem similares a uma costumeira roupeta inaciana, fazendo com que qualquer jesuíta que assim se trajasse pudesse se identificar (e ser identificado), o chapéu grande, talvez orientalizante poderia remeter a um lugar específico do seu trabalho missionário. Essa aderência a modelos orientalizantes pode ser pensada a partir da circulação de peças, obras e modelos pictóricos entre as partes oriental e ocidental do Império Português entre os séculos XVII e XVIII. Mais do que isso, para além do gosto pelo exotismo das peças do Oriente, podemos entender sua presença na América como "objetos memoriais da grandeza pretérita de um império universal, estando ao mesmo tempo inseridas na justificação escatológica de dominação dos Braganças" após a expulsão quase total dos portugueses da Ásia (com exceção de Goa e Macau). ${ }^{78}$ Para além dos objetos em si, houve a incorporação de elementos orientalizantes

76 Cf. André Reinoso, "São Francisco Xavier instituindo o símbolo da Cruz na Índia portuguesa", 1619, Óleo sobre tela, Sacristia da Igreja de S. Roque, Lisboa; Manuel Franco, Cenas da vida de São Francisco Xavier: "Milagre" e "Morte", século XVII, óleo sobre tela, Museu de Évora, Évora.

77 RICCI, Matteo. De Christiana expeditione apud Sinas suscepta ab Societate Jesu ex P. Matthæi Ricij eiusdem Societatis com [m]entarijs... in quibus Sinensis Regni mores, leges atq. instituta \& novæ illius Ecclesiæ difficillima primordia accurate \& summa fide describuntur. Augsburgo: Christoph. Mangium, 1615, frontispício.

78 BAUMGARTEN, Jens. Anacronismo e alteridade na arte colonial, p.99. 
nas igrejas e escolas dos jesuítas, em parte, também pela circulação de irmãos pelas partes do Império. Poucas décadas antes de se comporem os altares laterais dedicados a Xavier e Inácio, por exemplo, atuou na Bahia como pintor o jesuíta francês Carlos Bellevile que estivera entre 1698 e 1708 na China, tendo passado algumas vezes por Goa. Belleville na sua volta do Oriente acabou por ficar no Brasil, onde faleceu em 1730, tendo sido responsável pela introdução de orientalismos e chinesices no seminário de Belém em Cachoeira, no Recôncavo. De 1708 até 1730 foi o irmão pintor encarregado do colégio e a da igreja de Salvador. Entre 1717 e 1722, pelo menos, convivera e trabalhara com ele Francisco Coelho, que virou o irmão pintor em exercício no Colégio da Bahia (e, portanto, da Igreja dos Jesuítas) desde a morte de Bellevile até talvez meados da década de 1750, quando foi para o Rio de Janeiro e lá faleceu em $1759 .{ }^{79}$ Sob sua supervisão, senão mesmo pelo seu pincel, é que teriam sido pintadas as nove telas retratando a vida de Xavier, incluso a do sonho do índio. Portuense, Coelho nunca esteve no Oriente, mas poderia conhecer imagens e desenhos das missões asiáticas por intermédio de Bellevile. E mesmo que não fosse por essa relação entre os dois irmãos pintores, como Serafim Leite apontou, "a comunicação com o Oriente, pela passagem de naus da Índia [no porto de Salvador], era constante". ${ }^{80}$

Se tiverem sido escolhas pictóricas, instigam-nos a pensar sobre as relações entre as missões nas Índias Orientais e Ocidentais, especialmente em um momento no qual o Atlântico português, nomeadamente o Estado do Brasil, ocupava o centro das preocupações do império lusitano. Ao misturar elementos, o autor da imagem talvez buscasse traduzir visualmente um esforço maior dos jesuítas em transformar Xavier em exemplo missionário também para as Indias Ocidentais e ao mesmo tempo mostrar que o trabalho jesuítico (e o Império Português) alcançava o orbe. Vieira realizara empresa semelhante ao dizer que, entre as finezas de Xavier, estava ter sido também, por meio de seus milagres, "peregrino com as mesmas maravilhas na América" que fora na Ásia, como afirmou no volume dedicado exclusivamente ao santo. Nos sermões que tratam dos sonhos, Xavier Dormindo, Vieira constantemente ligou as visões oníricas à missão, ao mesmo tempo, jesuítica e portuguesa, em particular, nas Américas. Seus três sonhos seriam, na proposta de Vieira, prefigurações dos trabalhos missionários da Companhia de Jesus na América. Estas partes eram as últimas do orbe a serem descobertas e, com isso, necessitavam desfrutar da fé cristã para que o Reino de Cristo na Terra, a quinta e última Monarquia fosse realizado. Algo que aconteceria, assim, sob os esforços dos jesuítas e com o auxílio de

79 LEITE, Serafim. História da Companhia de Jesus no Brasil, p.217, p.228-230, p.248-249; PEREIRA, Sonia Gomes. Artistas e artífices da Catedral de Salvador, antiga igreja dos Jesuítas na Bahia, p.491-492.

80 LEITE, Serafim. História da Companhia de Jesus no Brasil, p.249. 
Portugal. ${ }^{81}$ Se nesses sermões sobre os sonhos de Xavier não há a menção explícita a uma proposta de Quinto Império, talvez tornando-os sobretudo prédicas mais concernentes ao exemplo cristão e devoção fiel, como ressaltou Isabel Almeida, ${ }^{82}$ nos sermões de Ação de Graças e Gratulatório a Xavier, ambos pelos nascimentos de príncipes da casa real portuguesa, a ligação é direta. Especialmente no de Ação de Graças, publicado no volume Palavra de Deus Empenhada e Desempenhada, pois até onde identificamos é o único dos mais de 200 sermões de Vieira no qual a expressão "Quinto Império" é utilizada de modo ostensivo e claramente relacionado ao Império Português ${ }^{83}$ - e num sermão que o exemplo de Xavier é central, pois não só protetor do reino mas responsável pelo nascimento do infante.

Podemos assim olhar a imagem na antiga Igreja dos Jesuítas tendo em vista também suas ligações com o Império Português. Nesse sentido, os dois signos não usuais (o garoto e o chapéu) ganham outra dimensão. Eram signos numa imagem de um santo que fora alçado a padroeiro da cidade de Salvador, que era tido como santo de Portugal e de seus domínios, que era exemplo da ação jesuíta no espaço ultramarino lusitano. Era talvez a tentativa de fazer um transplante do Apóstolo do Oriente para o Ocidente americano, sem perder de vista a unidade da missão e do Império. Santo que pregou no Oriente, vestido em trajes asiáticos, carregando um africano, que sustentava com seu trabalho escravo o Império, numa igreja americana, situada na cabeça daquela parte do mundo, então alçado a Vice-Reino do Brasil.

Nesse percurso iconográfico, Xavier de inícios do século XVII não é o mesmo Xavier de finais do XVII e de meados do XVIII, momentos nos quais o programa visual da Igreja dos Jesuítas foi estabelecido, seja na sacristia seja nos altares laterais. O santo missionário jesuíta de 1622, aquele que livrou grande parte das almas do Oriente dos males da gentilidade, era no final do mesmo século também aquele que era ligado à América, como símbolo do papel da Companhia de Jesus para a saída dos povos destas partes de sua ignorância da "verdadeira fé". As pinturas com o tema de sua morte e suas visões dormindo, em circulação na Europa e na América, corroboravam essa ideia ao veiculá-lo em meio aos ameríndios convertidos, ao mesmo tempo em que a introdução de elementos orientalizantes nas representações americanas lembravam o alcance universal (católico) da missão e do império. Xavier, de apóstolo de uma parte do mundo, torna-se

81 VIEIRA, Antônio. Xavier dormindo, e Xavier accordado, p.1-137. Ver. LIMA, Luís Filipe S. Sonho e missão em padre Vieira.

82 ALMEIDA, Isabel. Um pé na terra, outro nas estrelas.

83 VIEIRA, Palavra de Deos empenhada, e desempenhada, p.115-116, p.119-120, p.123, p.130, p.133. 
exemplo máximo do missionário de todo o globo, mas especialmente do Novo Mundo, parte a ser convertida para que o império universal de Cristo pudesse se consumar. Sua presença na Bahia por meio dos escritos de Vieira, da política iconográfica da igreja jesuíta e da consumada eleição como padroeiro de Salvador operavam no mesmo sentido. Mas, ao fazêlo, localizavam a cabeça desse império em Portugal, reforçando de modo inequívoco a ligação entre a Companhia e a coroa lusitana, como também a importância da conversão e conquista da América pelos jesuítas e portugueses. 